\title{
Fluid-driven Cyclic Reorganisation in Shallow Basaltic Fault Zones
}

Bob Bamberg ${ }^{1}$, Richard Walker ${ }^{1}$, Marc Reichow ${ }^{1}$, Audrey Ougier-Simonin ${ }^{2}$

${ }^{1}$ School of Geography, Geology, and the Environment, University of Leicester, University Road, Leicester LE1 7RH, United Kingdom

${ }^{2}$ Rock Mechanics and Physics Laboratory, British Geological Survey, Nicker Hill, Keyworth, Nottingham NG21 5GG, United Kingdom

\section{Contact Details}

B. Bamberg: bobbamberg@gmail.com (corresponding author)

R. Walker: rich.walker@le.ac.uk

M. Reichow: mkr6@le.ac.uk

A. Ougier-Simonin: audreyo@bgs.ac.uk

\section{Keywords}

Fault evolution, basalt, fluid flow, cementation, weakening, alteration

This manuscript is a preprint submitted to Geosphere and has not yet undergone peer-review. If accepted, the published version may include slight changes to the text and figures, and can be accessed via a link on the article webpage. 


\title{
Fluid-driven Cyclic Reorganisation in Shallow Basaltic Fault Zones
}

\author{
Bob Bamberg, Richard Walker, Marc Reichow, Audrey Ougier-Simonin
}

\begin{abstract}
Faults represent a critical heterogeneity in basaltic sequences, yet their architectural and hydromechanical evolution is poorly constrained. We present a detailed multi-scale characterisation of passively exhumed fault zones from the layered basalts of the Faroe Islands, which reveals cyclic stages of fault evolution. Outcrop-scale structures and fault rock distribution within the fault zones were mapped in the field and in 3D virtual outcrop models, with detailed characterisation of fault rock microstructure obtained from optical and SE-microscopy. The fault zones record localisation from decametre-wide Riedel shear zones into metre-wide fault cores, containing multiple cataclastic shear bands and low strain lenses organised around a central principal slip zone (PSZ). Shear bands and the PSZ consist of (ultra-) cataclasites with a zeolite-smectite assemblage replacing the original plagioclase-pyroxene host rock composition. Low-strain lenses are hydrothermal breccias of weakly altered host rock, or reworked fault rocks. PSZ-proximal zones show significant late-stage dilatation in the form of hydrothermal breccias or tabular veins with up to decimetre apertures. We interpret these structures as evolving from alternating shear-compaction and dilation through hydrofracture. The fault core preserves PSZ reworking, evidencing repeated shear zone locking and migration. The alternating deformation styles of shear-compaction and dilatation suggest episodic changes in deformation mechanisms driven by transient overpressure and release. The fault zone mechanical properties are thus governed by the combined effects of permanent chemical weakening and transient fluid-mediated mechanical weakening, alternating with cementation and healing.
\end{abstract}

\section{Introduction}

Basalt-hosted fluid reservoirs are essential for mitigating anthropogenic global warming through their high potential for geothermal energy and heat extraction (Aradóttir et al., 2015, Marieni et al., 2018), $\mathrm{CO}_{2}$ storage via mineral carbonation (Mcgrail et al., 2006, Matter et al., 2016, Snæbjörnsdóttir et al., 202O), and potentially $\mathrm{H}_{2}$ storage (Al-Yaseri \& Jha, 2021). Safe and successful operation in these fields can only be achieved through reliable hydrological, chemical, and mechanical reservoir characterisation (Guerreiro et al., 2000, Hangx et al., 2015, Juncu et al., 2020). Faults are a first order control on reservoir-scale permeability heterogeneity as they transect the typical stratigraphy of aquifers in flow tops (also known as interflow zones) and aquitards in the massive flow interiors (e.g.: Burt et al., 2009, Pollyea \& Fairley, 2012). Faults may act as channels, baffles, or barriers at different stages of their growth evolution or at different positions along individual fault zones (e.g.: Caine et al., 1996, Tenthorey et al., 2003, Uehara \& Shimamoto, 2004, Walker et al., 2013a, Walker et al., 2013b). Consequently, faults can either enhance crossstratigraphic fluid flow, connecting interflow aquifers, or compartmentalise basaltic reservoirs. Similarly, pre-existing fault zones may be reactivated as a response to production related fluid pressure increase (i.e., induced seismicity) (Cappa \& Rutqvist, 2011, Flóvenz et al., 2015, Juncu et al., 2020), but may also be stabilised by a net fluid loss, e.g., through geothermal extraction. 
The architecture of faults is commonly simplified in models, as representing a strain gradient from a highly deformed fault core, through a less deformed damage zone, and into intact host rock. Recent studies (e.g.: Faulkner et al., 2003) propose a considerably more complex organisation at deeper crustal levels or in weakened host rocks, featuring less-deformed fault rock lenses hosted in anastomosing cataclastic shear bands. The anastomosing macrostructure arises from shear zone locking and slip migration as a consequence of strain- or mineralisation-hardening (Faulkner et al., 2003, Caine et al., 2010, Callahan et al., 2020). Other faults show evidence for periodic roughening through slip zone segmentation, followed by progressive smoothing through frictional wear (Sagy \& Brodsky, 2009, Brodsky et al., 2011). Alternatively, large-scale roughening could be the result of fault linkage and the formation of subsidiary faults (Childs et al., 1996, Candela et al., 2009, Candela \& Renard, 2012). All of these models have a commonality in that they are characterised by episodic delocalisation and fault zone dilatation followed by failure and frictional shear, which can be preserved in discrete fault rock assemblages.

Cyclic models for fault evolution have not been expanded for basalt-hosted fault zones at reservoir depth. This is however crucial since basalt-hosted fault zones may behave differently to siliciclastic fault rocks because of the high chemical reactivity of their basaltic host mineralogy. Basalts undergo pervasive fluid-mediated alteration during fault evolution (Kristmannsdottir, 1979, Walker et al., 2013a), with the new mineral assemblage drastically changing bulk-rock mechanical properties (Shimamoto \& Logan, 1981, Haines et al., 2013, Boulton et al., 2014), such as replacement of frictionally strong feldspar-dominated assemblages by weak zeolites or clay minerals (e.g. Carpenter et al., 2016). These petrographic changes not only affect the mechanical structure, but also the permeability structure of the fault (Walker et al., 2013a, Walker et al., 2013b), which may affect fault strength and stability.

Although much work has been dedicated to understanding the evolution of fault zones in basalts, these studies mainly focus on fissure-type surface breaching faults (e.g. Holland et al., 2006, Bubeck et al., 2018, Von Hagke et al., 2019), and/or on fault growth in units with a strong mechanical anisotropy such as cooling joints (e.g. Walker et al., 2012, Kettermann et al., 2019, Weismüller et al., 2019). Little is known about fault evolution behaviour in crystalline basalt units at reservoir depth. In this study, we propose a model for shallow basaltic fault zone evolution based on multi-scale structural characterisation of fault assemblages, based on three exceptionally well exposed fault zones in the Faroe Islands.

\section{Geology and Faulting in the Faroe Islands}

The Faroe Islands are a small archipelago situated between the Shetland Islands and Iceland in the NE-Atlantic Ocean (Figure 1A). The archipelago is a subaerial remnant of the Paleogene North Atlantic Large Igneous Province, resulting from the initial outburst of the Icelandic Plume situated on what is now the SE shore of Greenland before the onset of Atlantic rifting (Ritchie \& Hitchen, 1996). The islands are composed almost exclusively of basaltic rocks of the Faroe Island Basalt Group (FIBG), including significant thicknesses of hyaloclastites and several volcaniclastic horizons, which extends for over $200 \mathrm{~km}$ to the E and SE of the archipelago (Passey \& Bell, 2007, Passey \& Jolley, 2008). The FIBG has a maximum stratigraphic thickness of ca. $6.6 \mathrm{~km}$, inferred from the slightly dipping surface exposure and the Lopra-1/1A borehole on Suduroy (Waagstein et al., 1984, Chalmers \& Waagstein, 2006, Passey \& Bell, 2007). However, more recent seismic studies point towards a lower maximum thickness of only about $3-4 \mathrm{~km}$ under the islands (Ólavsdóttir et al., 2017). The 
FIBG is subdivided into seven formations that record several periods of volcanic activity with a transition from submarine hyaloclastites to subaerial lavas (Passey \& Jolley, 2008). A detailed characterisation of the Faroes stratigraphy is provided by Passey \& Jolley (2008). Initiation of volcanic activity is placed between 60.1 Ma and 55.8 Ma (Hansen et al., 2002, Waagstein et al., 2002, Storey et al., 2007, Passey \& Jolley, 2008), with volcanic cessation before 54.5 Ma (measured in correlated units in Greenland and the Faroe-Shetland Basin, Larsen et al., 1999, Hansen et al., 2002, Larsen \& Tegner, 2006).

The structural evolution of the Faroe Islands is dominantly influenced by the opening of the NEAtlantic Ocean. Six stages of brittle structures on the islands record a progressive anticlockwise rotation of the horizontal extension vector within a continental relay zone between the advancing Reykjanes and Aegir Ridges, with an eventual switch to shortening as a result of abandonment of the Aegir Ridge in favour of the Kolbeinsey Ridge north of Jan Mayen (Gaina et al., 2009, Walker et al., 2011, Gernigon et al., 2012, Bubeck et al., 2017). Deformation was accommodated initially by dipslip faults and conjugate dykes accommodating NE-SW extension (stages 1-2 respectively), and by conjugate dykes and strike-slip faults accommodating N-S extension (stages 3-4 respectively), followed by NW-SE extension on strike-oblique slip faults (stage 5) (Walker et al., 2011). A late-stage overprint deformation (stage 6 ) is also recognised by reactivation of stage 1-5 structures (Walker et al., 2011). Early deformation overlaps with the last stages of FIBG emplacement as continental rifting began around $55-53 \mathrm{Ma}$, and tectonic activity continued at least into the mid Miocene (Roberts \& Walker, 2016, Ólavsdóttir et al., 2017).

We focus on three fault zones in the Faroe Islands (Figure 1B), representing three different displacement scales. The smallest fault is located near Í Botni on Suðuroy which shows about $30 \mathrm{~m}$ of dip-slip displacement, and is a N-S striking stage 1 fault (Walker et al., 2011) hosted in the extensive sheet lobes of the Beinisvørð Formation. The inferred middle-displacement fault is at Gøtugjógv, Eysturoy: an ENE-WSW trending sinistral strike-slip fault zone with about $500 \mathrm{~m}$ displacement. The inferred largest fault is the E-W trending fault zone at Selatrað, Eysturoy with ca. $1.5 \mathrm{~km}$ displacement. Displacements are inferred from offsets of the fjord separating Eysturoy and Streymoy (Figure 1C), which is a topographic and bathymetric feature that represents a NW-SE normal fault and/or dyke system (Ellis et al., 2009). The Gøtugjógv and Selatrað faults are stage 4 structures (Walker et al., 2011) and outcrop in the thinly bedded compound lavas of the Malinstindur Formation. The timing of fault activity is constrained by $\mathrm{U}-\mathrm{Pb}$ dating of calcite cements performed by Roberts \& Walker (2016): late-stage fault zones returned mid Eocene ages (44.8 - 40.1 Ma). A tentative, significantly younger, early Miocene (19.4 \pm 3.0 Ma) measurement for Gøtugjógv (see their Supplementary data) could indicate either long term permeability preservation or hint at the longevity of periodic fault activity presented in this study. Early faults (including Í Botni), did not return $\mathrm{U}-\mathrm{Pb}$ ages, but stratigraphic thickness variations across the fault zones indicate syn-volcanic emplacement (Passey \& Bell, 2007, Walker et al., 2011). Structural analysis of the fault zones indicate that I Botni is a fairly juvenile fault, with little displacement relative to its fault zone width (30 $\mathrm{m} v \mathrm{vs}$ $50 \mathrm{~m}$ ) and scarce evidence of widespread veining and mineralisation, which are common among more mature Faroese fault zones (Walker et al., 2012). In contrast, both Gøtugjógv and Selatrað have hectometre displacements and most likely represent consecutive stages of mature faulting. Gøtugjógv displays exceptional exposure of the fault core, whereas Selatrað allows more insight into the structure of the damage zone. 


\section{Fault Zone Architecture}

\section{1 Í Botni}

The fault zone at Í Botni (IBO, Figure 2) accommodates about $30 \mathrm{~m}$ E-down displacement, and is composed of multiple arrays of very steep faults distributed over a ca. $50 \mathrm{~m}$ thick zone. As highlighted by a red clay marker horizon (blue line in Figure $2 \mathrm{C}$ ), the majority of the displacement is accommodated across the easternmost fault strand. The steep topography of the outcrop and its proximity to the shoreline renders most of the fault zone inaccessible. Fortunately, the lower few tens of metres of the easternmost fault core have some accessible sections. Here, the principal slip zone (PSZ) is a $\leq 50 \mathrm{~cm}$ thick zone of grey to light brown, cohesive to incohesive, chaotic breccia, gouge, and some cataclasite (fault rock nomenclature from Woodcock \& Mort, 20o8) bounded by striated and polished black slip surfaces (Figure 8A). These structures are bound by similar but cohesive fine-grained chaotic breccia and cataclasite, which grade to coarser breccias and eventually undeformed host rock to either side.

\subsection{Gøtugjógv}

The Gøtugjógv fault zone (GOT, Figure 3) is exposed in a $50 \mathrm{~m}$ long and up to $10 \mathrm{~m}$ high rock face that reveals a section through the $2-3 \mathrm{~m}$ thick fault core, from the hanging wall damage zone in the west to the footwall in the east (Figure 3). The exposed damage zone consists of crackle breccia with clasts that gradually coarsen away from the core, and is about $10 \mathrm{~m}$ thick in the hanging wall and $3 \mathrm{~m}$ thick in the footwall. Veins or cement are rare and limited to thin zeolite veins and calcite or zeolite mineralisation on slip surfaces. Similar to the damage zone, the ca. $3 \mathrm{~m}$ thick core (spanning all current and abandoned PSZs) has an asymmetric structure in the exposed section, the most prominent PSS cuts across the core in direct contact with the hanging wall damage zone (Figure $3 \mathrm{C}$, Figure 4B). The PSZ consists of foliated and unfoliated cataclasites hosting a smooth principal slip surface (PSS) with an average orientation of $194 / 56^{\circ}$ (dip azimuth/dip angle) and slickenlines plunging 104/08 ${ }^{\circ}$ (azimuth/plunge angle) (Figure $4 \mathrm{E}$ ). The PSS is corrugated at the metre scale, with corrugations exposed over the $10 \mathrm{~m}$ high outcrop. As indicated in Figure 4 , the corrugations represent individual lenses of fault rock separated by networks of thin cataclastic shear bands and/or slip surfaces. Lenses either contain breccias or cataclasite, the latter being more prevalent in the PSZ. The transition from low strain to high strain fault rock is usually distinct (across a surface) but can also be gradual. Further away from the PSS the fault rock lenses increase in size, and potentially cover the entire exposed area at the level of the damage zone contact. Thicknesses of cataclastic shear bands range within the centimetre scale. The core also hosts abundant zeolite and calcite veins, with tabular veins along cataclastic shear bands, either following the contacts or within the bands. Veins are in places stacked as $5^{-10} \mathrm{~cm}$ thick composite veins, especially closer to the PSS (Figure 3D), or swarms of millimetre-aperture veinlets. The thick vein stacks feature well-developed slickensides between individual veins and on their contact with the wall rock (Figure 3D). Tabular veins are dominantly parallel, or orthogonal to the main fault orientation.

\subsection{Selatrad}

The Selatrad fault zone (SEL) is exposed in a $<30 \mathrm{~m}$ deep and $600 \mathrm{~m}$ long gorge separated into two tiers-deeper in the west and shallower in the east-by a waterfall ca. $200 \mathrm{~m}$ from the western end. Most of the ca. $7 \mathrm{~m}$ thick fault core lies underneath the river carving the gorge. Nevertheless, several anastomosing slip zones enclosing breccia lenses are exposed (Figure 5D). The most 
prominent slip zone dips northward and can be traced along the southern edge of the gorge (i.e. the footwall) in the upper eastern tier of the gorge, then curves towards the northern edge (i.e. the hanging wall) as the gorge deepens into the lower western tier at the waterfall seen in Figure $5 \mathrm{E}$. This PSZ hosts a very well-defined smooth PSS with centimetre to decimetre wavelength subhorizontal grooves along its entire exposure. On the upper tier, the slip surface is composed of a $5^{-10} \mathrm{~cm}$ thick ultracataclasite. In the lower tier exposures, the PSS is either composed of a similar ultracataclasite layer, or a coarser and less cohesive cataclasite grading into a chaotic breccia a few centimetres away from the PSS. An anastomosing network of large secondary faults runs parallel to the PSS and compartmentalises the fault core into a network of fault bounded lenses (Figure $5 \mathrm{E} \&$ F). These lenses are much less altered and fragmented than their bounding cataclastic shear bands. Figure $5 \mathrm{~F}$ is a map view of one of these lenses showing internal fragmentation by fractures in Riedel configuration and dominated by R shears. Similarly, large secondary faults are abundant in the damage zone, and are usually defined by a distinct and continuous corrugated slip surface sandwiched between a centimetre-thick layer of cataclasite to either side. Veins and cements are abundant in the core, but virtually absent from the damage zone. The average main fault orientation measured along the gorge floor is $000 / 71^{\circ}$ with slickenlines plunging $088 / 08^{\circ}$. However, the slightly less steep topographic orientation of the gorge $\left(\mathrm{ca} .00 \mathrm{o} / 6 \mathrm{o}^{\circ}\right.$ ) may be more indicative of overall fault zone orientation.

\subsection{Fault \& Fracture Orientation}

Since different measuring techniques were required to extract fault orientation data, at different scales, in the field, virtual outcrop models, and orthophotos, we can only compare the three fault zones qualitatively. In Gøtugjógv and Selatrað fault orientation has been measured in the field and reconstructed from the 3D virtual outcrop models (Figure 6). The latter method incurs uncertainty because: (1) the intersected rock faces generally have little relief, and fitting planes to fault traces is therefore dependent on the accuracy of the modelled surface and the position of the picked lineament; and (2) minor-displacement ( $\mathrm{mm}-\mathrm{cm}$ scale) fault surfaces may be composite structures that are below the resolution of the models. For instance, Walker et al. (2012: e.g., their Figure 4) showed that surfaces of $\mathrm{mm}-\mathrm{cm}$ scale displacement faults associated with stage 4 comprised linked faults and fractures that ranged in strike from ca. $060^{\circ}-115^{\circ}$ on a fault trace with an overall trend of ca. $060^{\circ}$. We also report a lineament analysis on orthophotos of a close-up of the Selatrad gully floor (Figure $5 \mathrm{~F}-\mathrm{G}$ ), which is almost flat, hence we are confident that fault traces are representative of fault strike, accurate to within ca. $5^{\circ}$.

The large-scale structure of the fault core and damage zone are strongly dominated by faults in $\mathrm{Y}$ to $\mathrm{R}$ orientation, as well as subordinate $\mathrm{P}$ faults (Figure 6). High angle shears (R' and X) are much less common and, in the case of the Selatra ${ }^{2}$ core (Figure $5 \mathrm{~F}$ ), occur mostly as late-stage structures that either fragment large clasts bounded by low-angle faults, or transect all other structures. We see similar high angle shears that transect the Gøtugjógv slip zone. This pattern is repeated on a smaller scale in centimetre- to decimetre-sized hand specimens, especially in foliated cataclasite (Figure 8B). Here R and P shears define a well-developed foliation bounded by fault-parallel Y shears separating different types of fault rock (e.g., ultracataclasite from cataclasite). Late-stage high-angle R'- and X-parallel shears cut through these boundaries as well as the foliation. Sense of slip along some of these high-angle shears is contrary to the typical Riedel configuration found in simple shear, indicating a pure shear (i.e., flattening) component to deformation. 


\section{Fault Rock Characterisation}

\section{1 Í Botni}

In the ca. $30 \mathrm{~m}$ displacement fault zone of I Botni damage concentration changes drastically over a very narrow zone. The PSS consists of a centimetre-wide swarm of anastomosing sub-millimetre thick, black, polished slip surfaces with clayey cataclasite in between (Figure 8A). The PSS is directly adjacent to crackle and chaotic breccias, that comprise largely unaltered basalt clasts in an authigenic cataclastic matrix (Figure 9 IBO-i \& ii, Figure 10A) on one side, and cataclasite or gouge with few relict clasts on the other side (Figure 9 IBO-iii). Initial XRD analyses show plagioclase and pyroxene to be preserved throughout most of the fault zone.

\subsection{Gøtugjógv}

\subsubsection{Breccias \& Veins}

Brecciation in the Gøtugjógv fault core is mostly related to hydrofracture (Figure 8E-G, Figure 9 GOT-iv \& viii - x) and associated with zeolite and calcite veins. Clast concentration in these breccia veins varies considerably, from domains that are potentially clast-supported to domains that are pure mineral vein (i.e., without clasts, Figure 7). Angular clasts ranging from sub-millimetre to centimetre scale are hosted in a cement of $<50 \mu \mathrm{m}$ long acicular - bladed zeolite, or equant calcite measuring a few millimetres across. The zeolite cement has a weak apparent shape-preferred orientation (SPO) forming a cross-shaped texture with axes at a $45^{\circ}$ angle with the vein boundaries (Figure 10E). A similar SPO can be seen in the matrix of some cataclasites (Figure 10F and paragraph below). The veins also contain numerous millimetre-sized pockets of irregular shape, with idiomorphic zeolite crystals protruding from the cement and often filled with a single crystal of calcite (Figure 9 GOT-viii \& x, Figure 1OE). Similarly, clasts of wall rock in calcite cemented breccias are commonly lined with syntaxial idiomorphic zeolite, and the cement contains millimetre sized pockets of zeolite. The clast population includes altered host rock (Figure 9 GOT-iv \& v), reworked fault rock (Figure 9 GOT-ix \& x), and in some cases larger fragments of older veins/cement (Figure 9 GOT-vii).

Many areas, especially along the contacts of different fault rock units, host centimetre-wide multiphase swarms of thin zeolite and calcite veinlets. Vein-internal reactivation is rare, more often veins propagate along the vein-wall rock interface, deflect from or cut across older veins, or take a new path through the wall rock. This suggests that mineral cements are stronger than the surrounding fault rock or altered host rock or the interface (Virgo et al., 2013). Veins and breccia cements record either extensive or no internal strain, as evidenced by twinning, inter- and intracrystalline cracking, and grain size reduction. Where interfaces host slickensides, the outer few millimetres of cement are comminuted and separated from unstrained inner layer by Y shears, as seen in Figure 9 GOT-viii.

A second class of small non-tabular veins can be observed in the domains further away from the PSS and especially in thicker cataclasite bodies. These zones are predominantly cemented by syntaxial bladed or blocky zeolite with a wide range of crystal sizes, and with equant calcite mineralisation also common. Their shape and orientation is irregular, frequently splaying, merging, and diverging, with variable aperture and orientation, with the wider segments hosting small fragments of wall rock (Figure 8G, Figure 9 GOT-xi). 
Some outcrop-scale breccia pods are markedly less organised and more homogenised than the previously described breccia veins. Their clasts are sub-angular to rounded with less distinct edges. Their concentration varies greatly, and they are hosted in a mixture of zeolite and clays (Figure 8D, Figure 9 GOT-vi).

\subsubsection{Cataclasites}

The textural transition from breccia to cataclasite and ultracataclasite is gradual (Figure 7). On the coarse end of the scale, cataclasites resemble the unorganised breccias described above. They have sub-angular to rounded clasts of fault rock and altered host rock hosted in a comminuted, authigenic clay-rich matrix with sparse, unconnected and irregularly shaped patches of cement (Figure 8B, Figure 9 GOT-ii). Finer cataclasites host fewer clasts, and the composition of those clasts is dominated by polycrystalline zeolite aggregates without clay, in a matrix of homogeneous zeolite, pyroxene, and clay (Figure 8C \& G, Figure 9 GOT-iii \& GOT-xi, Figure 10D, G \& H). In some cases, the zeolites have an acicular habit defining a lattice-shaped SPO inclined to the slip plane, similar to zeolite cement in veins (Figure 10F). In the hanging wall PSZ, the clay minerals show a clear foliation. Mesoscopic foliation is defined by millimetre thick clay bands parallel to the R, P, and Y orientation (Figure 8B, Figure 9 GOT-ii) and only developed in the coarser cataclasite outside the PSS. Microscopic foliation is defined by very thin and continuous clay bands at a higher angle to the slip surface $\left(40-55^{\circ}\right)$ and is only developed in the ultracataclasite (Figure $10 \mathrm{G} \& \mathrm{H}$ ). Late-stage highangle fractures (red in Figure 8B) commonly transect and offset all other structures, layer boundaries (i.e., ultracataclasite to cataclasite), foliation, and other shear bands/fractures. They are parallel to the R' orientation but their sense of shear can be both synthetic and antithetic, indicating compaction. Further, Scanning Electron Microscope-Backscattered Electron (SEM-BSE) imaging shows that the cataclasites maintain a significant porosity even in high strain examples (Figure 10I).

\subsection{Selatrað}

The sampled PSS ultracataclasite (Figure 9 SEL-iii) is texturally very similar to the abandoned red clay ultracataclasite from the Gøtugjógv fault core (Figure 9 GOT-xi). As part of the current PSZ it has not been brecciated or cut by zeolite veins, but the texture is nearly identical, showing a red clay-dominated matrix with very fine-grained pyroxene fragments and larger polymineralic clasts. Many of these clasts contain calcite, and calcite vein fragments can be identified indicating prior stages of veining within the fault. The weakly consolidated cataclasite that can be found along parts of the PSS in the lower tier, is dominated by a red clay matrix and contains polymineralic clasts that are up to $5 \mathrm{~cm}$ across, but are commonly millimetre-scale sizes. Clast concentration gradually increases away from the slip surface and the rock can be classified as mosaic breccia some $30 \mathrm{~cm}$ from the slip surface. Consequently, the internal structure of fault rock lenses is dominated by mosaic and crackle breccias with a systematic fragmentation along R to R'.

As mentioned above, secondary faults in the damage zone are sandwiched by cataclasite layers to either side. They are usually only a few centimetres wide, even for extensive and polished slip surfaces. Boundaries to the undeformed wall rock can be distinct or gradual. The cataclasite layer is strongly altered. In the case of the fault zone-oblique narrow cataclastic band in Figure 9 SEL-i, the assemblage has completely changed to zeolite and remnant pyroxene with an undulating boundary of $\mathrm{R}$ and $\mathrm{Y}$ shears to the unaltered wall rock. The fault zone parallel and slightly wider slip zone in Figure 9 SEL-ii grades from a zeolite and clay dominated cataclasite on the left through a brecciated zone with angular and weakly altered wall rock clasts in a zeolite cement. Throughout the damage zone, wall rocks show no, or only minor, alteration. 
During initial fault growth, fault rock evolution is driven by cataclasis, as can be seen in the brecciated and comminuted rocks from Í Botni. In mature faults, like Gøtugjógv and Selatrað, hydrofracture is responsible for initial brecciation of entrained host rock or embrittled fault rock. Unless cements become the dominant component of the newly formed rocks (i.e., they are fault veins), they then evolve by cataclastic flow, manifesting through increasing concentrations of highly comminuted matrix at the expense of larger clasts and cement (Figure 7).

\section{Fault Zone Evolution}

The three analysed fault zones represent three displacement scales and can therefore be treated conceptually as progressive stages in the evolution of basaltic faults, from tens-of-metre scale to potentially hundreds-of-metre- or kilometre-scale displacement, and metre to tens-of-metre thickness respectively. These fault zones expand the displacement scaling for faults in basaltic rocks described in Walker et al. (2012, 2013b) by up to two orders of magnitude, and provide new insights into the evolution stages and processes that occur within mature fault zones.

The faults record a cyclic evolution, with localised cataclastic flow during subseismic slip or creep, alternating with episodic core embrittlement and extensive hydrofracture and cementation. Based on our observations, we present a multistage model for fault zone evolution in basaltic rocks (Figure 11), described in the following.

Stage 1: Fault zones initiate in arrays of small faults in Riedel configuration, as preserved in the damage zone of Selatrað (Figure 3 \& Figure 6), which link to create a network of continuous larger faults localising strain (Peacock, 1991, Peacock \& Sanderson, 1995, Walsh et al., 2003, Childs et al., 2009, Candela \& Renard, 2012, Rotevatn et al., 2019), as seen in Í Botni (Figure 2).

Stage 2: Continued localisation results in formation of a fault core that accommodates the bulk of displacement across the fault. Shear within the core results in the formation of a highly comminuted cataclastic principal slip zone (PSZ, e.g., Í Botni, Figure 2).

Stage 3: Formation of fine-grained fault rocks in the PSZ and pervasively fractured lenses of damage zone rocks, which comprise a host rock mineralogy dominated by plagioclase and pyroxene, are almost completely replaced by a clay and zeolite assemblage. The timing of fluid-mediated alteration is constrained by the weakly altered Í Botni fault core and local alteration around damage zone fractures in Gøtugjógv and Selatrað (Figure 9 \& Figure 10). All three faults should show extensively altered damage zones if alteration preceded damage concentration.

Stage 4: The reduction in grain size and increase in clay content within the fault core reduces permeability and fluid flow within the fault. Increases in fluid pressure cannot be drained within the fault core, which leads to hydrofracture, both as discrete veins and pervasive brecciation, followed by rapid mineralisation by zeolite and calcite (e.g., Gøtugjógv, Figure 9 GOT-iv - xi), potentially leading to permanent fault core thickening.

Stage 5: Following extensive mineralisation and cementation, the PSZ relocates into a less cemented domain. Minor displacement on Riedel shears, associated with continued deformation, cause steps in the boundary of abandoned older PSZ, which are entrained into the newly forming PSZ, resulting in reworking of previous generations of fault rock, and the formation of clasts of existing clasts (e.g., Figure 8G and Figure 9 GOT-xi). 
Stages 6-7: Fragmentation in the abandoned core follows Riedel orientations as can be seen in Figure 8B, transecting and offsetting older shear planes. As a result of comminution causing homogenisation and embrittlement of the fault core, rock texture resembles that from stage 3 again. Fluid pressure rises, and the cycle continues.

\section{Discussion}

Fault slip commonly triggers fluid pressure transients (e.g. Wibberley et al., 2008, Faulkner et al., 2010, Bense et al., 2013), which can destabilise the fault and lead to extensive failure (Byerlee, 1993). Equally, progressive permeability decrease and fluid pressurisation during creep promote fault slip. Recent studies by Callahan et al. (2020) and Proctor et al. (2020) highlight how fluid flow can become the dominant driving force for fault evolution and stability, eclipsing more classical structural and mechanical considerations, such as slip zone geometry or rate-and-state friction. Fluids can exert a direct control on stability by modulating the effective stress field acting on the fault zone, as has been well established elsewhere. At the macroscopic scale, faults can trap fluids and maintain near lithostatic internal fluid pressure throughout the entire brittle domain (Byerlee, 1990). However, heterogenous permeability distribution can compartmentalise the fault zone, with slight variations in fluid pressure, making them more or less prone to failure (Byerlee, 1993). Following a localised failure of one of these compartments, the resulting fluid-pressure transient can have knock-on effects on the neighbouring compartments, causing runaway failure of the fault, as well as allowing intermittent fluid flow through the fault zone; a process known as fault valve behaviour (Sibson, 1990, Byerlee, 1993). On a smaller scale, low permeability granular rocks such as cataclasites and gouges can experience fluid pressure peaks during shear as they cannot drain fast enough to compensate for internal porosity destruction during deformation. Here too, a transient fluid pressure increase leads to dynamic weakening (Ikari et al., 2009, Faulkner et al., 2018). Fluids also contribute to fault strengthening, by catalysing the dissolution-precipitation reactions of fault healing (Gratier, 2011). In natural fault zones, these processes lead to cyclic activity recorded in overprinting generations of fault rocks. The faults commonly have a high inherent structural heterogeneity with anastomosing slip zones enclosing breccia lenses, leading to compartmentalisation (Faulkner et al., 2003, Caine et al., 2010). Fluid pressure transients trigger failure and slip (Sutherland et al., 2012), followed by dilatancy, pressure-boiling, and mineralisation (Caine et al., 2010, Sutherland et al., 2012, Callahan et al., 2020). Embrittlement through cementation strengthens the fault and may force slip migration into adjacent, weaker structures, but also primes the fault for a next failure (Caine et al., 2010, Gratier, 2011, Sutherland et al., 2012, Callahan et al., 2020).

\subsection{Fluid Flow \& Chemical Alteration}

Pervasive alteration in the fault zone is limited to fractured rocks and is a result of damage localisation that enhances fluid channelling (Figure 9 IBO-i - ii, SEL-i, GOT-i \& Figure 9A). The fault rocks from the low displacement fault in Í Botni preserve their original plagioclase-pyroxene assemblage in most collected samples, with the heavily altered and reworked footwall PSZ (Figure 9 IBO-iii) being the only exception. Even the breccias in direct contact with the PSS in the hanging wall show only minimal alteration around their clasts that does not penetrate more than 0.1-0.5 mm into the clasts (Figure 9 IBO-i - ii). Likewise, in the Gøtugjógv and Selatrað damage zones, alteration does not extend beyond the fracture and vein walls (Figure 9 GOT-i, GOT-xii, SEL-i \& Figure 1OB). This is contrasted by the complete textural and mineralogical breakdown observed in the Gøtugjógv 
and Selatrað fault cores, which are composed of a clay-zeolite assemblage with remnant pyroxene (e.g., Figure 9 GOT-ii, GOT-vi, GOT-xi, SEL-iii). Wall rock clasts entrained in the core consistently show strong alteration, even though their texture may be preserved (Figure 9 GOT-iv \& Figure 10C). The inferred alteration sequence is in line with permeability variation measured along basaltic faults in the Faroes Islands by Walker et al. (2013a, 2013b), who recorded elevated permeability in the fault cores, which are insulated laterally by low permeability damage zones; a configuration that promotes fault-parallel fluid channelling.

Fault core permeability is strongly linked to the interplay between comminution and clay generation (permeability reduction), and the establishment of interconnected and porous (zeolite) vein networks and microdamage (permeability increase) (Sutherland et al., 2012, Walker et al., 2013a), but also to local strain concentration and petrographic heterogeneity along the fault (Caine et al., 2010, Sutherland et al., 2012). For example, clay-dominated cataclasite or gouge is more readily sealed than zeolite-dominated chaotic breccia. Since the integrity, continuity, and abundance of veins, mineralised breccias, and clay-dominated shear bands, varies strongly throughout the mature fault zones in Gøtugjógv and Selatrað, we can expect strong internal compartmentalisation and significant fluid pressure variations along the fault zones, depending on the volume of entrapped fluid and the degree of local compaction (Byerlee, 1993, Caine et al., 2010, Sutherland et al., 2012). The cyclicity of compartment sealing, overpressurisation, and hydrofracture that we infer, especially in Gøtugjógv, would cause fluid pumping and considerable transient effective stress variations, leading to failure (Byerlee, 1993, Eichhubl \& Boles, 200o, Caine et al., 2010, Warren-Smith et al., 2019, Callahan et al., 2020). This is summarized in Figure 12, which presents a conceptual illustration of the permeability and fault strength evolution expected through the faulting cycle. As with compartmentalisation leading to fluid pressurisation on a large scale, low permeability fault rocks are susceptible to dynamic internal pressurisation on a much smaller scale. Their low permeability prevents fluids from draining from the rocks to equilibrate pressure increases from porosity destruction during shear-compaction (Sleep \& Blanpied, 1992, Ikari et al., 2009, Faulkner et al., 2018). Combined, fluid trapping and pressurisation provides a mechanism for fluid pressure cycling and repeated mineralisation events, without the need of an external fluid source feeding the fault zones.

Most of the studied cataclasites have a very high zeolite concentration in their matrix as well as abundant zeolite and calcite vein fragments. We can infer that a significant portion of the matrix zeolite derives from secondary mineralisation and not just from reworking of zeolitised host rock alone. In that case, zeolite is progressively added to the fault zone, either through precipitation in veins and breccias over several mineralisation cycles, or by continuous precipitation into microporosity opened during dilatant cataclastic flow (Stel, 1981, Hadizadeh \& Foit, 2000). Both processes are likely to contribute to the high zeolite concentration and necessitate an active fluid circulation. Considering the prevalence of veins and the high ratio of zeolite over calcite veins currently preserved in the fault zone, we infer that pressure cycling with intermittent hydrofracture is effective at introducing zeolite as opposed to calcite.

\subsection{Fault Core Widening}

Core thickness of the studied faults increases from about $0.5^{-1.0} \mathrm{~m}$ in Í Botni (30 $\mathrm{m}$ displacement), to 2-3 $\mathrm{m}$ in Gøtugjógv (ca. $500 \mathrm{~m}$ displacement), and $7 \mathrm{~m}$ in Selatrað (ca. $1.5 \mathrm{~km}$ displacement). These values also consistently range on the higher end of core thickness distribution (Shipton et al., 2006). This could indicate that the faults have a low seismic potential as they effectively dissipate energy by fracturing processes and frictional slip (Mckay et al., 2021). The 
complex internal geometry, with strong strain partitioning between brecciated lenses and cataclastic shear bands suggests repeated assimilation of less deformed wall rock into the fault core. Callahan et al. (2020) recently proposed combined fluid-driven cyclic dilatation and mineralisation, alternating with embrittlement and shear deformation, as well as damage zone assimilation during fault core stepping, as widening processes for the Dixie Comstock fault, a process that has also been inferred for the Stillwater fault by Caine et al. (2010). We see evidence for both processes in the studied fault zones: thick veins and widespread mineralisation in the Gøtugjógv core and abundant fragments of reworked older veins in fault rocks supporting the mineralisation-deformation cycles; and relatively unaltered wall rock fragments with preserved textures found in low strain lenses indicating wall rock ablation. Following their integration into the fault core, these lenses were fragmented and assimilated through frictional wear processes (Sagy et al., 2007, Childs et al., 2009, Brodsky et al., 2011). The widespread occurrence of heavily altered fault rock fragments derived from frictional shear within mineralised portions of the Gøtugjógv fault, indicates that alteration weakening did not promote the development of a stable permanent slip zone, contrary to what has been suggested for the Dixie Comstock (Callahan et al., 2020). We will discuss several potential mechanisms for internally driven fault core migration in more detail below, as this step is crucial to our evolutionary model. However, wall rock ablation can also be driven externally through linkage of fault segments and secondary faults, cutting off large lenses of damage zone rock as well as introducing slip surface corrugation of the same geometric scale as the wall rock lenses (Childs et al., 2009, Candela \& Renard, 2012). This process seems to be dominant at earlier stages of fault zone evolution, as seen in the wide and low displacement fault zone at Í Botni.

\subsection{Fault Strength}

Fault strength is governed by the interplay between fault structure and rock mechanics, chemical influences, and episodic effective stress variations (Faulkner et al., 2010). Local structure is a first order control as the distribution and geometry of slip surfaces and fault rocks influence strain partitioning within the fault zone (e.g. Moore \& Byerlee, 1992, Faulkner et al., 2003, Caine et al., 2010, Gratier, 2011, Renard \& Candela, 2017). The generation of thick layers of cataclasite around a relatively smooth principal slip surface provides evidence for shear localisation within the PSZ. Strain is most likely transferred gradually from distributed granular flow within the cataclasite (or even breccias) after fault core resetting, onto localised smooth slip surface later in the cycle. This implies a general strain-hardening behaviour of the cataclasites (Sagy \& Brodsky, 20o9), probably as an effect of progressively reduced grain size (Eberhardt et al., 1999). Microscopically, increasing clay content favours the development of a clayey foliation and Riedel shears, effectively concentrating strain and significantly reducing overall rock strength as stronger components are bypassed due to the low friction coefficient of the clay framework and localised shears (Tembe et al., 2010). Weakening through shear fabric development is thought to be particularly effective in clays as their small grain size allows for deformation in very thin shear planes without significant dilation or cataclasis (Haines et al., 2013).

The chemical control on fault rock strength is defined by the opposing influences of alterationweakening and mineral cementation-strengthening. The introduction of fluids around in the fault zone results in the chemical breakdown of strong plagioclase, into clays and zeolite, characterised by a significantly reduced mechanical strength (Saffer \& Marone, 2003, Tembe et al., 2010, YukselenAksoy, 2010, Frolova et al., 2014, Morrow et al., 2017), thus permanently weakening the rock. In the evolved fault rocks described above, the chemical influence on strength is mainly characterised by episodic mineralisation with zeolite and calcite, both in (breccia) veins and disseminated throughout 
the fault rock (Stel, 1981, Hadizadeh \& Foit, 2000). This results in a transient strengthening through the direct effect of cementation (e.g. Caine et al., 2010, Callahan et al., 2020), but also a long-term increase in strength as the overall composition progressively shifts towards more zeolite and calcite relative to clay minerals. Since zeolite and calcite veins don't usually reactivate each other internally but preferably emplace in the wall rock or along vein walls, we infer that they are stronger than the clay-dominated wall rock or the vein-wall rock interface (Virgo et al., 2013). This is also shown by the presence of well-developed slickensides on the vein interfaces (Figure 3D) showing that shear preferentially localises here before disrupting the veins. The overall efficiency of healing processes active on slip surfaces is promoted by the high reactivity of zeolites and calcite and the catalysing effect of fluids, but is impeded by the less reactive clay minerals (Gratier, 2011, Renard et al., 2012). Analysis of post-seismic fluid chemistry on the analogous Húsavík-Flatey Fault in Iceland shows full hydrochemical recovery, assumed to mirror fracture healing by mineral precipitation, after about 8-10 years even though it is delayed by minor refracturing events (Wästeby et al., 2014). It should be noted that mechanical recovery by mineralisation does not necessarily imply full sealing of fluid pathways (Aben et al., 2017).

Immediately before and during slip, the effect of fluid pressure changes imposed by compaction and dilation can exceed the fault rock's intrinsic frictional characteristics to become the dominant control on fault stability (Proctor et al., 2020). As described previously, compartmentalisation results in considerable local fluid pressure variation within the fault zone. If one such compartment fails, rapid fluid flow creates a high fluid pressure transient that can migrate through the fault zone (Byerlee, 1993). The associated effective stress drop is evidenced by numerous implosion breccias throughout Gøtugjógv, and centimetre-scale calcite crystals in veins, requiring fractures to be maintained open over a substantial period of time, potentially 100 s to 1000 s of years (Lee \& Morse, 1999, Frery et al., 2015). Even in the absence of an external fluid pressure transient, creep of saturated granular fault rock (i.e. gouge or cataclasite) can result in internal overpressure through shear compaction and ineffective fluid drainage from the low permeability rocks (Sleep \& Blanpied, 1992, Ikari et al., 2009, Faulkner et al., 2018). In both scenarios the effective pressure reduction entails mechanical weakening (Ikari et al., 2009, Morrow et al., 2017, Faulkner et al., 2018), and eventually fluid overpressure and hydrofracture, especially in thicker granular layers (Faulkner et al., 2018). Besides the direct effects on fault shear strength by effective pressure reduction, episodic fluid flow mediates many of the permanent and transient chemical processes previously described, such as alteration-weakening, mineralisation-strengthening, and healing. The combined effects of transient changes to permeability and fault strength are illustrated in Figure 12.

\subsection{Slip Zone Locking \& Migration}

Reworked clasts of cataclasites within the fault cores indicate stages of PSZ migration. This implies that previously active PSZs became unfavourable for continued slip, despite the development of relatively weak clay assemblages: i.e., they became locked. The fault rock (micro-) structure provides evidence for several processes that could contribute to slip zone hardening and locking, which are outlined below.

(1) PSS \& PSZ dissection: High-angle shears dissecting strain-concentrating structures, juxtaposing low-strength and high-strength structures, e.g. clay foliation and zeolite matrix or gouge and cataclasite (Figure 8B), increases the bulk strength of the slip zone and can result in PSZ locking. Should these high-angle shears form during slip, they would have to accumulate their small displacements at a much higher rate than the slip rate on the PSS to prevent bypassing or progressive removal and incorporation of any emerging asperities into the adjacent 
gouge/cataclasite layer. More likely, the observed high-angle shears developed in one of two scenarios: during post-slip creep, forcing subsequent slip to relocate into another structure, or during fragmentation of an embrittled and abandoned slip zone in the vicinity of a new PSZ. Sagy \& Brodsky (2009) identified similar layer transecting structures as an important process for reroughening mature slip zones and propose that they are a type of boudinage structure emerging from the rheological contrast developed as a consequence of strain hardening in the cataclasite/gouge layer.

(2) Zeolite recrystallisation: The apparent zeolite SPO recorded in some cataclasite, resembling the apparent SPO observed in veins (Figure $9 \mathrm{E} \& \mathrm{~F}$ ), implies a similar process of formation and is most likely the result of recrystallisation as the elongated zeolite habit (acicular bladed) inhibits grain rotation necessary for granular flow in cataclasite and gouge. Material science studies have shown that many natural and synthetic zeolites readily dissolve and reprecipitate in alkaline conditions under atmospheric pressure and temperatures below ca. $110^{\circ} \mathrm{C}$ (e.g. Ivanova \& Knyazeva, 2013). This is similar to the conditions thought necessary to favour zeolite over calcite precipitation in Icelandic basalts (Neuhoff et al., 2000). If reactivity in the PSZ is high enough for recrystallisation to outpace comminution, it is also likely to allow for healing of the slip surface during aseismic creep (Renard et al., 2012), leading to overall strengthening of the slip system. However, the observed SPO could also be a result of post-shear recrystallisation, in which case it would only contribute to strength recovery after a slip event.

(3) Cementation: The prevalence of fresh and reworked veins, hydrofractured breccias, and the almost bimodal strain distribution in cements-either intact or highly strained-demonstrate periodic fluid overpressure and mineralisation in the fault core. Cyclic fluid pressurisation and hydrofracture is commonly observed in both seismogenic (e.g. Byerlee, 1993, Eichhubl \& Boles, 200o, Caine et al., 2010, Callahan et al., 2020) as well as slow slip faults (Warren-Smith et al., 2019). As noted above, permeability can drop significantly within high strain gouge and cataclasite, especially in clay-rich assemblages, through porosity compaction. To allow for repeated pressurisation, porosity could be reset by fluidisation during high-velocity slip events (Sleep \& Blanpied, 1992, Ikari et al., 2009, Faulkner et al., 2018). While we observed no strong evidence for gouge fluidisation (Monzawa \& Otsuki, 2003, Otsuki et al., 2003), the reworking of fault rocks by granular flow after PSZ migration offers a viable alternative process to reintroduce porosity. In any case, cataclasites clearly show open pore space in SEM-BSE images (Figure 10I) as well as fabric elements originating from compaction (e.g. Figure 8B). It is evident that fluids in the PSZ were overpressured and led to extensive hydrofracture. This would have caused a transient decrease of frictional strength, triggering rapid, potentially even seismic slip (Byerlee, 1993, Faulkner et al., 2018). The ensuing pressure drop would lead to pressure boiling and mineral precipitation, strengthening the slip zone and potentially shutting it down (Caine et al., 2010, Wästeby et al., 2014, Callahan et al., 2020).

(4) Strain hardening: Smectite-rich gouges have been shown to be dominantly strainhardening (Saffer \& Marone, 2003, Tembe et al., 2010, Boulton et al., 2014, Morrow et al., 2017), which could also significantly contribute to the cyclicity of fault rock production and PSZ migration. Shutdown and migration of cataclastic slip zones as a result of strain-hardening has been proposed for example in the Carboneras fault zone in Spain (Faulkner et al., 2003) as well as the Flowers Pit fault zone in the USA (Sagy \& Brodsky, 20o9, Brodsky et al., 2011). Progressive strain wears down asperities, producing fine-grained material and thickening the cataclastic layer. Smoothing of the slip surface, lubrication by gouge, and strain-hardening in the cataclastic layer lead to slip localisation onto the PSS. This is counteracted by lump removal of asperities and boudinage-like 
transection of the embrittled cataclasite layer, deforming and re-roughening the adjacent PSS, thus allowing continuous reworking and generation of gouge/cataclasite (Candela et al., 2009, Sagy \& Brodsky, 2009, Brodsky et al., 2011). Such a process could explain gouge/cataclasite production in fault sections without extensive mineralisation such as those exposed in Selatrað.

\section{Conclusion}

The studied fault zones in the Faroe Islands indicate that basalt-hosted fault zones can evolve through repeated principal slip zone migration and fault rock reworking. After an initial phase of permanent chemical weakening promotes strain localisation into a principal slip zone, phases of stable cataclastic shear alternate with hydrofracture followed by pervasive cementation of the principal slip zone. The mechanical properties are governed by an interplay between coeval and successive weakening and strengthening processes: Comminution and increasing clay concentration in the principal slip zone lead to mechanical weakening through fluid pressure increases, while strengthening processes are either mechanical, in the form of strain-hardening of the granular fault rocks, or chemical, in the case of fluid-mediated cementation and healing. Mechanical and chemical strengthening culminate in locking of the slip zone and force the fault to reorganise around a weaker structure, restarting a new cycle of cataclastic shear. Fluids play a critical role in the structural and mechanical evolution of basaltic faults, through their catalysing effects for chemical alteration of the fault rocks, as a transport medium in dissolution-precipitation processes cementing the fault zone, and in modulating effective stress within the fault zone.

\section{References}

Aben, F., Doan, M. L., Gratier, J. P. \& Renard, F. 2017. Experimental Postseismic Recovery of Fractured Rocks Assisted by Calcite Sealing. Geophysical Research Letters, 44, 7228-7238.

Al-Yaseri, A. \& Jha, N. K. 2021. On Hydrogen Wettability of Basaltic Rock. Journal of Petroleum Science and Engineering, 200, 108387.

Aradóttir, E. S., Gunnarsson, I., Sigfússon, B., Gíslason, S. R., Oelkers, E. H., Stute, M., Matter, J. M., Snaebjörnsdottir, S. Ó., Mesfin, K. G., Alfredsson, H. A., Hall, J., Arnarsson, M. T., Dideriksen, K., Júliusson, B. M., Broecker, W. S. \& Gunnlaugsson, E. Towards Cleaner Geothermal Energy: Subsurface Sequestration of Sour Gas Emissions from Geothermal Power Plants. Proceedings World Geothermal Congress 2015, 19-25 April 20152015 Melbourne, Australia.

Bense, V. F., Gleeson, T., Loveless, S. E., Bour, O. \& Scibek, J. 2013. Fault Zone Hydrogeology. Earth-Science Reviews, 127, 171-192.

Boulton, C., Moore, D. E., Lockner, D. A., Toy, V. G., Townend, J. \& Sutherland, R. 2014. Frictional Properties of Exhumed Fault Gouges in Dfdp-1 Cores, Alpine Fault, New Zealand. 41, 356-362.

Brodsky, E. E., Gilchrist, J. J., Sagy, A. \& Collettini, C. 2011. Faults Smooth Gradually as a Function of Slip. Earth and Planetary Science Letters, 302, 185-193.

Bubeck, A., Walker, R. J., Imber, J., Holdsworth, R. E., Macleod, C. J. \& Holwell, D. A. 2017. Extension Parallel to the Rift Zone During Segmented Fault Growth: Application to the Evolution of the Ne Atlantic.

Bubeck, A., Walker, R. J., Imber, J. \& Macleod, C. J. 2018. Normal Fault Growth in Layered Basaltic Rocks: The Role of Strain Rate in Fault Evolution. Journal of Structural Geology, 115, 103-120.

Burt, W., Conlon, T. D., Tolan, T. L., Wells, R. E. \& Melady, J. 2009. Hydrogeology of the Columbia River Basalt Group in the Northern Willamette Valley.

Byerlee, J. 1990. Friction, Overpressure and Fault Normal Compression. Geophysical Research Letters, 17, 2109-2112.

Byerlee, J. D. 1993. Model for Episodic Flow of High-Pressure Water in Fault Zones before Earthquakes. Geology, 21, 303-306.

Caine, J. S., Bruhn, R. L. \& Forster, C. B. 2010. Internal Structure, Fault Rocks, and Inferences Regarding Deformation, Fluid Flow, and Mineralization in the Seismogenic Stillwater Normal Fault, Dixie Valley, Nevada. Journal of Structural Geology, 32, 1576-1589.

Caine, J. S., Evans, J. P. \& Forster, C. B. 1996. Fault Zone Architecture and Permeability Structure. Geology, 24, 1025-1028.

Callahan, O. A., Eichhubl, P. \& Davatzes, N. C. 2020. Mineral Precipitation as a Mechanism of Fault Core Growth. Journal of Structural Geology, 140, 104156.

Candela, T. \& Renard, F. 2012. Segment Linkage Process at the Origin of Slip Surface Roughness: Evidence from the Dixie Valley Fault. Journal of Structural Geology, 45, 87-100. 
Candela, T., Renard, F., Bouchon, M., Brouste, A., Marsan, D., Schmittbuhl, J. \& Voisin, C. 20o9. Characterization of Fault Roughness at Various Scales: Implications of Three-Dimensional High Resolution Topography Measurements. Mechanics, Structure and Evolution of Fault Zones. Springer.

Cappa, F. \& Rutqvist, J. 2011. Modeling of Coupled Deformation and Permeability Evolution During Fault Reactivation Induced by Deep Underground Injection of Co2. International Journal of Greenhouse Gas Control, 5, 336-346.

Carpenter, B. M., Ikari, M. J. \& Marone, C. 2016. Laboratory Observations of Time-Dependent Frictional Strengthening and Stress Relaxation in Natural and Synthetic Fault Gouges. Journal of Geophysical Research: Solid Earth, 121, 1183-1201.

Chalmers, J. A. \& Waagstein, R. 2006. Scientific Results from the Deepened Lopra-1 Borehole, Faroe Islands, Geological Survey of Denmark and Greenland, Danish Ministry of the Environment.

Childs, C., Manzocchi, T., Walsh, J. J., Bonson, C. G., Nicol, A. \& Schöpfer, M. P. J. 20og. A Geometric Model of Fault Zone and Fault Rock Thickness Variations. Journal of Structural Geology, 31, 117-127.

Childs, C., Nicol, A., Walsh, J. J. \& Watterson, J. 1996. Growth of Vertically Segmented Normal Faults. Journal of Structural Geology, 18, 1389-1397.

Eberhardt, E., Stimpson, B. \& Stead, D. 1999. Effects of Grain Size on the Initiation and Propagation Thresholds of Stress-Induced Brittle Fractures. Rock mechanics and rock engineering, 32, 81-99.

Eichhubl, P. \& Boles, J. R. 2000. Rates of Fluid Flow in Fault Systems; Evidence for Episodic Rapid Fluid Flow in the Miocene Monterey Formation, Coastal California. American Journal of Science, 300, 571-60o.

Ellis, D., Passey, S. R., Jolley, D. W. \& Bell, B. R. Transfer Zones: The Application of New Geological Information from the Faroe Islands Applied to the Offshore Exploration of Intra and Sub-Basalt Strata. Faroe Islands Exploration Conference: Proceedings of the 2nd Conference, 2009. Annales Societatis Scientiarum Færoensis, 205-226.

Faulkner, D., Jackson, C., Lunn, R., Schlische, R., Shipton, Z., Wibberley, C. \& Withjack, M. 2010. A Review of Recent Developments Concerning the Structure, Mechanics and Fluid Flow Properties of Fault Zones. Journal of Structural Geology, 32, 15571575 .

Faulkner, D. R., Lewis, A. C. \& Rutter, E. H. 2003. On the Internal Structure and Mechanics of Large Strike-Slip Fault Zones: Field Observations of the Carboneras Fault in Southeastern Spain. Tectonophysics, 367, 235-251.

Faulkner, D. R., Sanchez-Roa, C., Boulton, C. \& Hartog, S. a. M. 2018. Pore Fluid Pressure Development in Compacting Fault Gouge in Theory, Experiments, and Nature. Journal of Geophysical Research: Solid Earth, 123, 226-241.

Flóvenz, Ó. G., Ágústsson, K., Guðnason, E. Á. \& Kristjánsdóttir, S. Reinjection and Induced Seismicity in Geothermal Fields in Iceland. 2015 .

Frery, E., Gratier, J.-P., Ellouz-Zimmerman, N., Loiselet, C., Braun, J., Deschamps, P., Blamart, D., Hamelin, B. \& Swennen, R. 2015. Evolution of Fault Permeability During Episodic Fluid Circulation: Evidence for the Effects of Fluid-Rock Interactions from Travertine Studies (Utah-USA). Tectonophysics, 651-652, 121-137.

Frolova, J., Ladygin, V., Rychagov, S. \& Zukhubaya, D. 2014. Effects of Hydrothermal Alterations on Physical and Mechanical Properties of Rocks in the Kuril-Kamchatka Island Arc. Engineering Geology, 183, 80-95

Gaina, C., Gernigon, L. \& Ball, P. 2009. Palaeocene-Recent Plate Boundaries in the Ne Atlantic and the Formation of the Jan Mayen Microcontinent. Journal of the Geological Society, 166, 601.

Gernigon, L., Gaina, C., Olesen, O., Ball, P., Péron-Pinvidic, G. \& Yamasaki, T. 2012. The Norway Basin Revisited: From Continental Breakup to Spreading Ridge Extinction. Marine and Petroleum Geology, 35, 1-19.

Gratier, J.-P. 2011. Fault Permeability and Strength Evolution Related to Fracturing and Healing Episodic Processes (Years to Millennia): The Role of Pressure Solution. Oil Gas Sci. Technol. - Rev. IFP Energies nouvelles, 66, $491-506$.

Guerreiro, L., Silva, A. C., Alcobia, V. \& Soares, A. 200o. Integrated Reservoir Characterisation of a Fractured Carbonate Reservoir. SPE International Petroleum Conference and Exhibition in Mexico. Villahermosa, Mexico: Society of Petroleum Engineers.

Hadizadeh, J. \& Foit, F. F. 200o. Feasibility of Estimating Cementation Rates in a Brittle Fault Zone Using Sr/Ca Partition Coefficients for Sedimentary Diagenesis. Journal of Structural Geology, 22, 401-409.

Haines, S. H., Kaproth, B., Marone, C., Saffer, D. \& Van Der Pluijm, B. 2013. Shear Zones in Clay-Rich Fault Gouge: A Laboratory Study of Fabric Development and Evolution. Journal of Structural Geology, 51, 206-225

Hangx, S., Bakker, E., Bertier, P., Nover, G. \& Busch, A. 2015. Chemical-Mechanical Coupling Observed for Depleted Oil Reservoirs Subjected to Long-Term Co2-Exposure-a Case Study of the Werkendam Natural Co2 Analogue Field. Earth and Planetary Science Letters, 428, 230-242.

Hansen, H., Pedersen, A., Duncan, R., Bird, D., Brooks, C., Fawcett, J., Gittins, J., Gorton, M. \& O'day, P. 20o2. Volcanic Stratigraphy of the Southern Prinsen Af Wales Bjerge Region, East Greenland. Geological Society, London, Special Publications, 197, $183-218$.

Holland, M., Urai, J. L. \& Martel, S. 2006. The Internal Structure of Fault Zones in Basaltic Sequences. Earth and Planetary Science Letters, 248, 301-315.

Ikari, M. J., Saffer, D. M. \& Marone, C. 2009. Frictional and Hydrologic Properties of Clay-Rich Fault Gouge. Journal of Geophysical Research: Solid Earth, 114.

Ivanova, I. I. \& Knyazeva, E. E. 2013. Micro-Mesoporous Materials Obtained by Zeolite Recrystallization: Synthesis, Characterization and Catalytic Applications. Chemical Society Reviews, 42, 3671-3688.

Juncu, D., Árnadóttir, T., Geirsson, H., Guðmundsson, G. B., Lund, B., Gunnarsson, G., Hooper, A., Hreinsdóttir, S. \& Michalczewska, K. 2020. Injection-Induced Surface Deformation and Seismicity at the Hellisheidi Geothermal Field, Iceland. Journal of Volcanology and Geothermal Research, 391, 106337.

Kettermann, M., Weismüller, C., Von Hagke, C., Reicherter, K. \& Urai, J. L. 2019. Large near-Surface Block Rotations at Normal Faults of the Iceland Rift: Evolution of Tectonic Caves and Dilatancy. Geology, 47, 781-785.

Kington, J. 2013. Mplstereonet. https://github.com/joferkington/mplstereonet: GitHub. 
Kristmannsdottir, H. 1979. Alteration of Basaltic Rocks by Hydrothermal-Activity at 100-300 C. Developments in Sedimentology. Elsevier.

Larsen, L. M., Waagstein, R., Pedersen, A. K. \& Storey, M. 1999. Trans-Atlantic Correlation of the Palaeogene Volcanic Successions in the Faeroe Islands and East Greenland. Journal of the Geological Society, 156, 1081-1095.

Larsen, R. B. \& Tegner, C. 2006. Pressure Conditions for the Solidification of the Skaergaard Intrusion: Eruption of East Greenland Flood Basalts in Less Than 300,00o Years. Lithos, 92, 181-197.

Lee, Y.-J. \& Morse, J. W. 1999. Calcite Precipitation in Synthetic Veins: Implications for the Time and Fluid Volume Necessary for Vein Filling. Chemical Geology, 156, 151-170.

Marieni, C., Přikryl, J., Aradóttir, E. S., Gunnarsson, I. \& Stefánsson, A. 2018. Towards 'Green'geothermal Energy: CoMineralization of Carbon and Sulfur in Geothermal Reservoirs. International Journal of Greenhouse Gas Control, 77, 96-105.

Matter, J. M., Stute, M., Snæbjörnsdottir, S. Ó., Oelkers, E. H., Gislason, S. R., Aradottir, E. S., Sigfusson, B., Gunnarsson, I., Sigurdardottir, H., Gunnlaugsson, E., Axelsson, G., Alfredsson, H. A., Wolff-Boenisch, D., Mesfin, K., Taya, D. F. D. L. R., Hall, J., Dideriksen, K. \& Broecker, W. S. 2016. Rapid Carbon Mineralization for Permanent Disposal of Anthropogenic Carbon Dioxide Emissions. Science, 352, 1312-1314.

Mcgrail, B. P., Schaef, H. T., Ho, A. M., Chien, Y. J., Dooley, J. J. \& Davidson, C. L. 20o6. Potential for Carbon Dioxide Sequestration in Flood Basalts. Journal of Geophysical Research: Solid Earth, 111.

Mckay, L., Lunn, R. J., Shipton, Z. K., Pytharouli, S. \& Roberts, J. J. 2021. Do Intraplate and Plate Boundary Fault Systems Evolve in a Similar Way with Repeated Slip Events? Earth and Planetary Science Letters, 559, 116757.

Monzawa, N. \& Otsuki, K. 2003. Comminution and Fluidization of Granular Fault Materials: Implications for Fault Slip Behavior. Tectonophysics, 367, 127-143.

Moore, D. E. \& Byerlee, J. 1992. Relationships between Sliding Behavior and Internal Geometry of Laboratory Fault Zones and Some Creeping and Locked Strike-Slip Faults of California. Tectonophysics, 211, 305-316.

Morrow, C. A., Moore, D. E. \& Lockner, D. A. 2017. Frictional Strength of Wet and Dry Montmorillonite. Journal of Geophysical Research: Solid Earth, 122, 3392-3409.

Neuhoff, P. S., Fridriksson, T. \& Bird, D. K. J. I. G. R. 2000. Zeolite Parageneses in the North Atlantic Igneous Province: Implications for Geotectonics and Groundwater Quality of Basaltic Crust. 42, 15-44.

Ólavsdóttir, J., Eidesgaard, Ó. R. \& Stoker, M. S. 2017. The Stratigraphy and Structure of the Faroese Continental Margin. Geological Society, London, Special Publications, 447, 339-356.

Otsuki, K., Monzawa, N. \& Nagase, T. 2003. Fluidization and Melting of Fault Gouge During Seismic Slip: Identification in the Nojima Fault Zone and Implications for Focal Earthquake Mechanisms. Journal of Geophysical Research: Solid Earth, 108.

Passey, S. R. \& Bell, B. R. 2007. Morphologies and Emplacement Mechanisms of the Lava Flows of the Faroe Islands Basalt Group, Faroe Islands, Ne Atlantic Ocean. Bulletin of Volcanology, 70, 139-156.

Passey, S. R. \& Jolley, D. W. 2008. A Revised Lithostratigraphic Nomenclature for the Palaeogene Faroe Islands Basalt Group, Ne Atlantic Ocean. Earth and Environmental Science Transactions of the Royal Society of Edinburgh, 99, 127-158.

Peacock, D. C. P. 1991. Displacements and Segment Linkage in Strike-Slip Fault Zones. Journal of Structural Geology, 13, 10251035 .

Peacock, D. C. P. \& Sanderson, D. J. 1995. Strike-Slip Relay Ramps. Journal of Structural Geology, 17, 1351-136o.

Pollyea, R. M. \& Fairley, J. P. 2012. Implications of Spatial Reservoir Uncertainty for Co 2 Sequestration in the East Snake River Plain, Idaho (USA). Hydrogeology Journal, 20, 689-699.

Proctor, B., Lockner, D., Kilgore, B., Mitchell, T. \& Beeler, N. 2020. Direct Evidence for Fluid Pressure, Dilatancy, and Compaction Affecting Slip in Isolated Faults. Geophysical Research Letters, 47, e2019GLo86767.

Renard, F., Beauprêtre, S., Voisin, C., Zigone, D., Candela, T., Dysthe, D. K. \& Gratier, J.-P. 2012. Strength Evolution of a Reactive Frictional Interface Is Controlled by the Dynamics of Contacts and Chemical Effects. Earth and Planetary Science Letters, 341-344, 20-34.

Renard, F. \& Candela, T. 2017. Scaling of Fault Roughness and Implications for Earthquake Mechanics. Fault Zone Dynamic Processes: Evolution of Fault Properties During Seismic Rupture, 227, 197-216.

Ritchie, J. \& Hitchen, K. 1996. Early Paleogene Offshore Igneous Activity to the Northwest of the Uk and Its Relationship to the North Atlantic Igneous Province. Geological Society, London, Special Publications, 101, 63-78.

Roberts, N. M. W. \& Walker, R. J. 2016. U-Pb Geochronology of Calcite-Mineralized Faults: Absolute Timing of Rift-Related Fault Events on the Northeast Atlantic Margin. Geology, 44, 531-534.

Rotevatn, A., Jackson, C. a. L., Tvedt, A. B. M., Bell, R. E. \& Blækkan, I. 2019. How Do Normal Faults Grow? Journal of Structural Geology, 125, 174-184.

Roubeyrie, L. \& Celles, S. 2018. Windrose: A Python Matplotlib, Numpy Library to Manage Wind and Pollution Data, Draw Windrose. Journal of Open Source Software, 3, 268.

Saffer, D. M. \& Marone, C. 2003. Comparison of Smectite- and Illite-Rich Gouge Frictional Properties: Application to the Updip Limit of the Seismogenic Zone Along Subduction Megathrusts. Earth and Planetary Science Letters, 215, 219-235.

Sagy, A. \& Brodsky, E. E. 2009. Geometric and Rheological Asperities in an Exposed Fault Zone. Journal of Geophysical Research: Solid Earth, 114 .

Sagy, A., Brodsky, E. E. \& Axen, G. J. 2007. Evolution of Fault-Surface Roughness with Slip. Geology, 35, 283-286.

Shimamoto, T. \& Logan, J. M. 1981. Effects of Simulated Fault Gouge on the Sliding Behavior of Tennessee Sandstone: Nonclay Gouges. Journal of Geophysical Research: Solid Earth, 86, 2902-2914.

Shipton, Z. K., Soden, A. M., Kirkpatrick, J. D., Bright, A. M. \& Lunn, R. J. 2006. How Thick Is a Fault? Fault DisplacementThickness Scaling Revisited. 
Sibson, R. H. 1990. Conditions for Fault-Valve Behaviour. Geological Society, London, Special Publications, 54, $15-28$.

Sleep, N. H. \& Blanpied, M. L. 1992. Creep, Compaction and the Weak Rheology of Major Faults. Nature, 359, 687-692.

Snæbjörnsdóttir, S. Ó., Sigfússon, B., Marieni, C., Goldberg, D., Gislason, S. R. \& Oelkers, E. H. 2020. Carbon Dioxide Storage through Mineral Carbonation. Nature Reviews Earth \& Environment, 1, 90-102.

Stel, H. 1981. Crystal Growth in Cataclasites: Diagnostic Microstructures and Implications. Tectonophysics, 78, 585-6oo.

Storey, M., Duncan, R. A. \& Tegner, C. 2007. Timing and Duration of Volcanism in the North Atlantic Igneous Province: Implications for Geodynamics and Links to the Iceland Hotspot. Chemical Geology, 241, 264-281.

Sutherland, R., Toy, V. G., Townend, J., Cox, S. C., Eccles, J. D., Faulkner, D. R., Prior, D. J., Norris, R. J., Mariani, E., Boulton, C., Carpenter, B. M., Menzies, C. D., Little, T. A., Hasting, M., De Pascale, G. P., Langridge, R. M., Scott, H. R., Lindroos, Z. R., Fleming, B. \& Kopf, A. J. 2012. Drilling Reveals Fluid Control on Architecture and Rupture of the Alpine Fault, New Zealand. Geology, 40, 1143-1146.

Tembe, S., Lockner, D. A. \& Wong, T. F. 2010. Effect of Clay Content and Mineralogy on Frictional Sliding Behavior of Simulated Gouges: Binary and Ternary Mixtures of Quartz, Illite, and Montmorillonite. Journal of Geophysical Research: Solid Earth, 115 .

Tenthorey, E., Cox, S. F. \& Todd, H. F. 2003. Evolution of Strength Recovery and Permeability During Fluid-Rock Reaction in Experimental Fault Zones. Earth and Planetary Science Letters, 206, 161-172.

Uehara, S.-I. \& Shimamoto, T. 2004. Gas Permeability Evolution of Cataclasite and Fault Gouge in Triaxial Compression and Implications for Changes in Fault-Zone Permeability Structure through the Earthquake Cycle. Tectonophysics, 378, $183-195$.

Virgo, S., Abe, S. \& Urai, J. L. 2013. Extension Fracture Propagation in Rocks with Veins: Insight into the Crack-Seal Process Using Discrete Element Method Modeling. Journal of Geophysical Research: Solid Earth, 118, 5236-5251.

Von Hagke, C., Kettermann, M., Bitsch, N., Bücken, D., Weismüller, C. \& Urai, J. L. 2019. The Effect of Obliquity of Slip in Normal Faults on Distribution of Open Fractures. Frontiers in Earth Science, 7, 18.

Waagstein, R., Guise, P. \& Rex, D. J. G. S., London, Special Publications 2002. K/Ar and 39ar/40ar Whole-Rock Dating of Zeolite Facies Metamorphosed Flood Basalts: The Upper Paleocene Basalts of the Faroe Islands, Ne Atlantic. 197, $219-252$.

Waagstein, R., Hald, N., Jørgensen, O., Nielsen, P. H., Noe, A., Jørgensen, O., Noe-Nygaard, A. \& Schonharting, G. 1984. Deep Drilling on the Faeroe Islands.

Walker, R. J., Holdsworth, R. E., Armitage, P. J. \& Faulkner, D. R. 2013a. Fault Zone Permeability Structure Evolution in Basalts. Geology, 41, 59-62.

Walker, R. J., Holdsworth, R. E., Imber, J. \& Ellis, D. 2011. Onshore Evidence for Progressive Changes in Rifting Directions During Continental Break-up in the Ne Atlantic. Journal of the Geological Society, 168, 27-48.

Walker, R. J., Holdsworth, R. E., Imber, J. \& Ellis, D. 2012. Fault-Zone Evolution in Layered Basalt Sequences: A Case Study from the Faroe Islands, Ne Atlantic Margin. GSA Bulletin, 124, 1382-1393.

Walker, R. J., Holdsworth, R. E., Imber, J., Faulkner, D. R. \& Armitage, P. J. 2013b. Fault Zone Architecture and Fluid Flow in Interlayered Basaltic Volcaniclastic-Crystalline Sequences. Journal of Structural Geology, 51, 92-104.

Walsh, J., Bailey, W., Childs, C., Nicol, A. \& Bonson, C. 2003. Formation of Segmented Normal Faults: A 3-D Perspective. Journal of Structural Geology, 25, 1251-1262.

Warren-Smith, E., Fry, B., Wallace, L., Chon, E., Henrys, S., Sheehan, A., Mochizuki, K., Schwartz, S., Webb, S. \& Lebedev, S. 2019. Episodic Stress and Fluid Pressure Cycling in Subducting Oceanic Crust During Slow Slip. Nature Geoscience, 12, 475481.

Wästeby, N., Skelton, A., Tollefsen, E., Andrén, M., Stockmann, G., Claesson Liljedahl, L., Sturkell, E. \& Mörth, M. 2014. Hydrochemical Monitoring, Petrological Observation, and Geochemical Modeling of Fault Healing after an Earthquake. Journal of Geophysical Research: Solid Earth, 119, 5727-5740.

Weismüller, C., Urai, J. L., Kettermann, M., Hagke, C. V. \& Reicherter, K. 2019. Structure of Massively Dilatant Faults in Iceland: Lessons Learned from High-Resolution Unmanned Aerial Vehicle Data. Solid Earth, 10, 1757-1784.

Wibberley, C. a. J., Yielding, G. \& Di Toro, G. 2008. Recent Advances in the Understanding of Fault Zone Internal Structure: A Review. Geological Society, London, Special Publications, 299, 5.

Woodcock, N. H. \& Mort, K. 2008. Classification of Fault Breccias and Related Fault Rocks. Geological Magazine, 145, 435-440.

Yukselen-Aksoy, Y. 2010. Characterization of Two Natural Zeolites for Geotechnical and Geoenvironmental Applications. Applied Clay Science, 50, 130-136. 


\section{Figures}

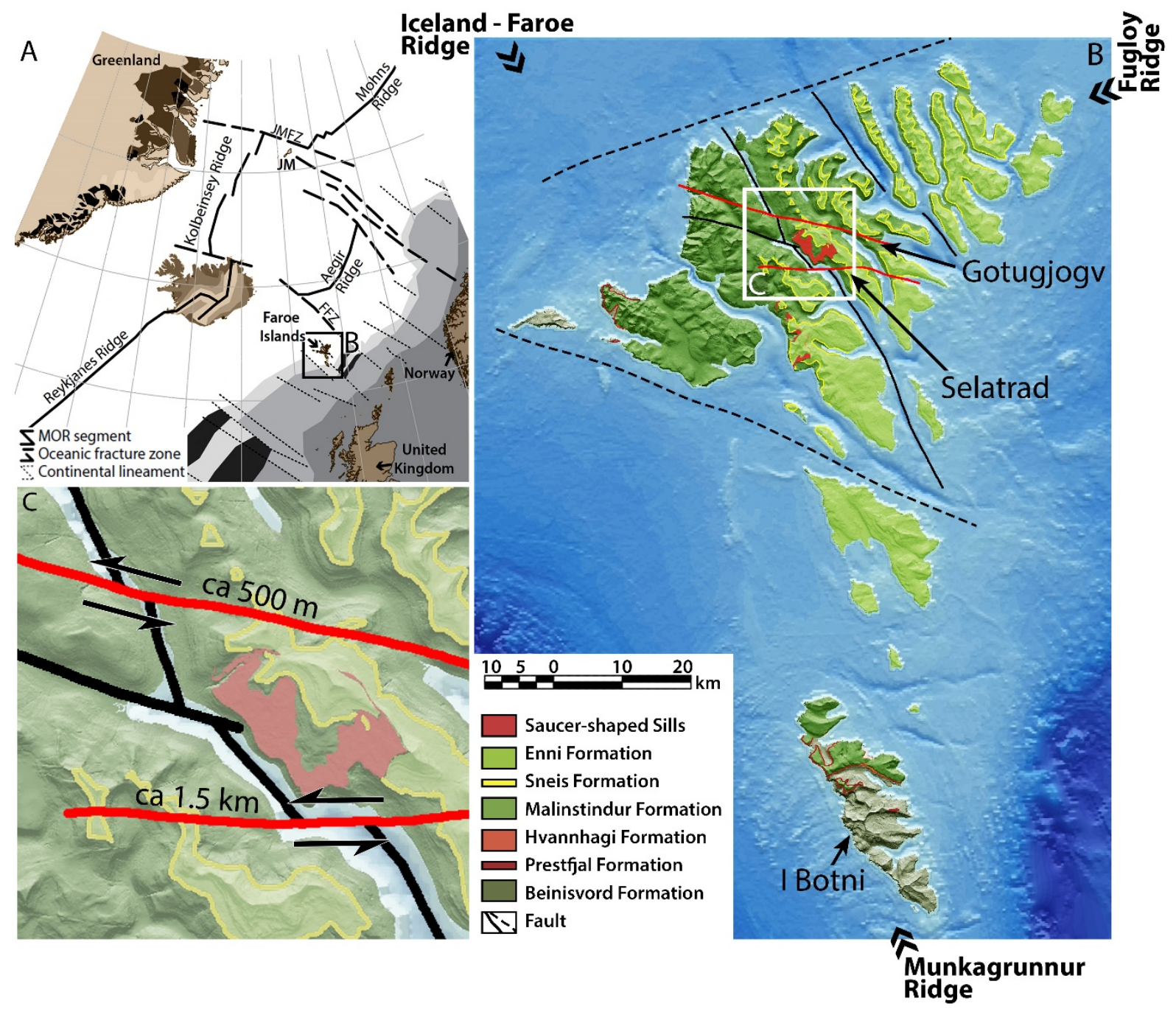

Figure 1: Structural overview and geological setting of the Faroe Islands. (A) The archipelago in the N-Atlantic sits on the intersection of three ocean ridges: the Iceland-Faroe Ridge in the NW, the Fugloy Ridge in the NE and the Munkagrunnur Ridge in the S (adapted from Roberts \& Walker, 2016). (B) We focus on three fault zones in this paper: Two large sinistral strike-slip faults exposed in Gøtugjógv and Selatrað (Eysturoy), and a smaller normal fault exposed in Í Botni (Suduroy). (C) The fjord separating Eysturoy (E) from Streymoy (W) has two major kinks in the continuation of the Gøtugjógv and Selatrað fault zones, indicating potential displacements of $500 \mathrm{~m}$ and $1.5 \mathrm{~km}$ respectively. 


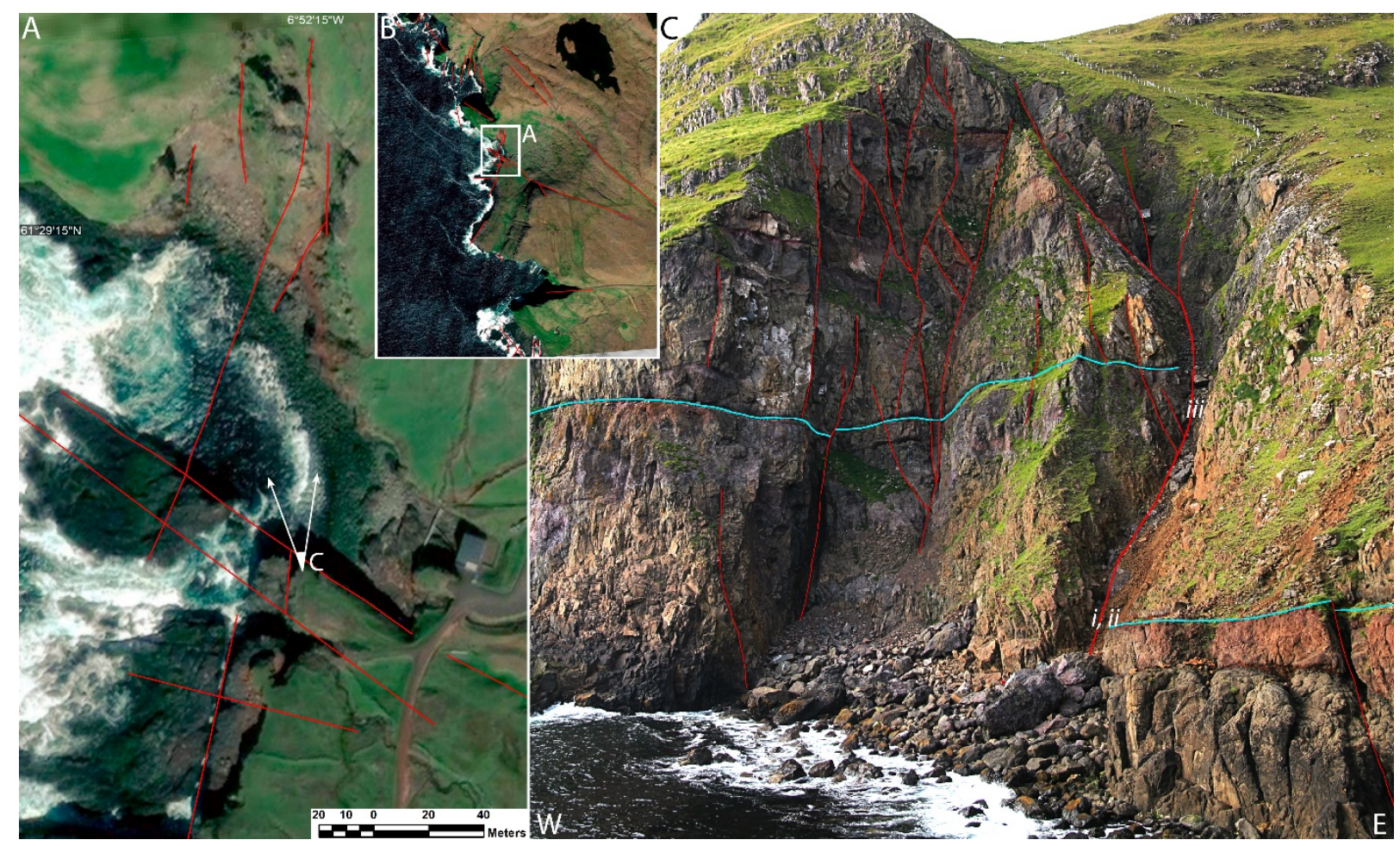

Figure 2: The Í Botni fault zone $\left(61^{\circ} 29^{\prime} 14^{\prime \prime} N 6^{\circ} 5^{\prime} 18^{\prime \prime} W\right)$ is a $50 \mathrm{~m}$ wide and very steep fault zone with an E-down sense of movement. Only the main fault strand concentrating essentially all of the $30 \mathrm{~m}$ displacement in the $E$ was sampled ( $\mathrm{i}-$ iii, Figure 8 - Figure 10). It has an average orientation of $280 / 69^{\circ}$ with striations plunging $303 / 82^{\circ}$. 

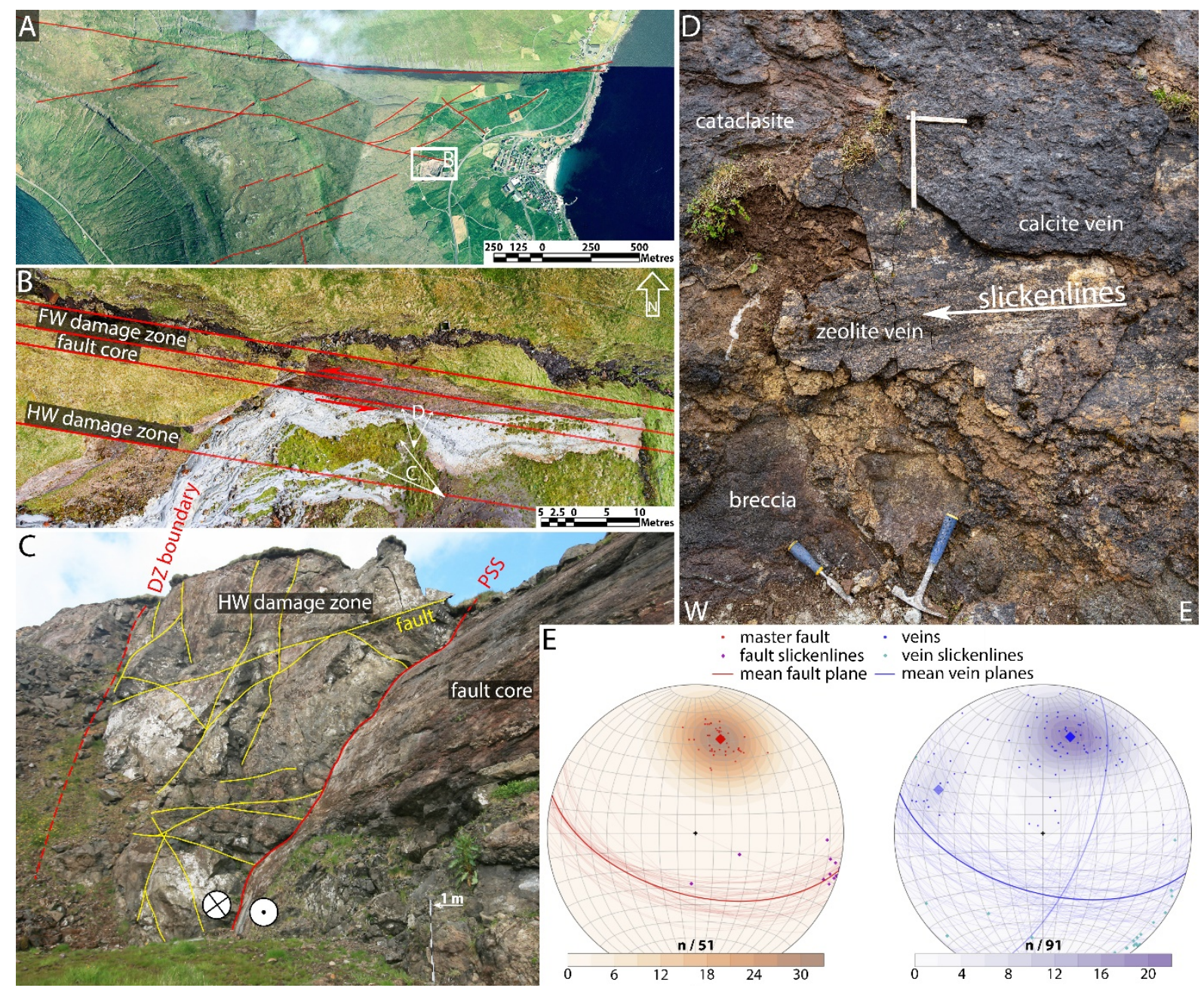

veins

vein slickenlines

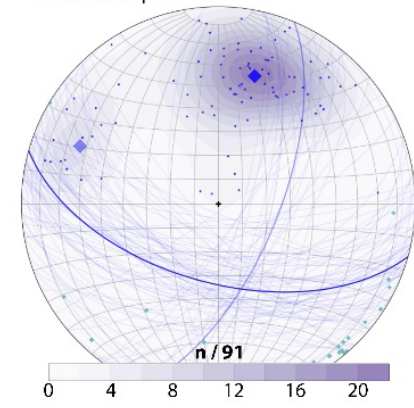

Figure 3: (A) The sinistral fault zone in Gøtugjógv ( $\left.62^{\circ} 11^{\prime} 11^{\prime \prime} N 6^{\circ} 45^{\prime} 47^{\prime \prime} W\right)$ is surrounded by a wide array of small Riedel faults. (B) A diagonal transect from the hanging wall damage zone in the $W$ to the footwall damage zone in the $E$ is exposed in a disused quarry. The exposed footwall section, containing most of the fault core is $50 \mathrm{~m}$ wide and up to $10 \mathrm{~m}$ high. (B \& $C$ ) The exposed section is distinctly asymmetrical. The damage zone is $10 \mathrm{~m}$ wide in the hanging wall as opposed to only $3 \mathrm{~m}$ in the footwall. The fault core however is mainly contained in the footwall, with only a width of 2-3 $\mathrm{m}$ vs 20-30 cm in the hanging wall. (C) The PSS is strongly corrugated, exposing 3-4 marked asperities. The ruler for scale is $1 \mathrm{~m}$ long. (D) Large patch of fault parallel veins exploiting the contact between two cataclasite lenses in the PSZ. The contact between the zeolite and calcite vein is smooth and heavily striated by sinistral slickenlines. Average orientation of slickenlines on the PSS and veins is 104/08 ${ }^{\circ}$. Ruler is $40 \times 20 \mathrm{~cm}$. (E) Average PSS orientation (red) is rather shallow for a strike-slip fault with $194 / 56^{\circ}$ and shows little scatter. The fault core hosts extensive veining (blue), predominantly parallel (74/91 veins) or orthogonal (17/91 veins) to the PSS. 


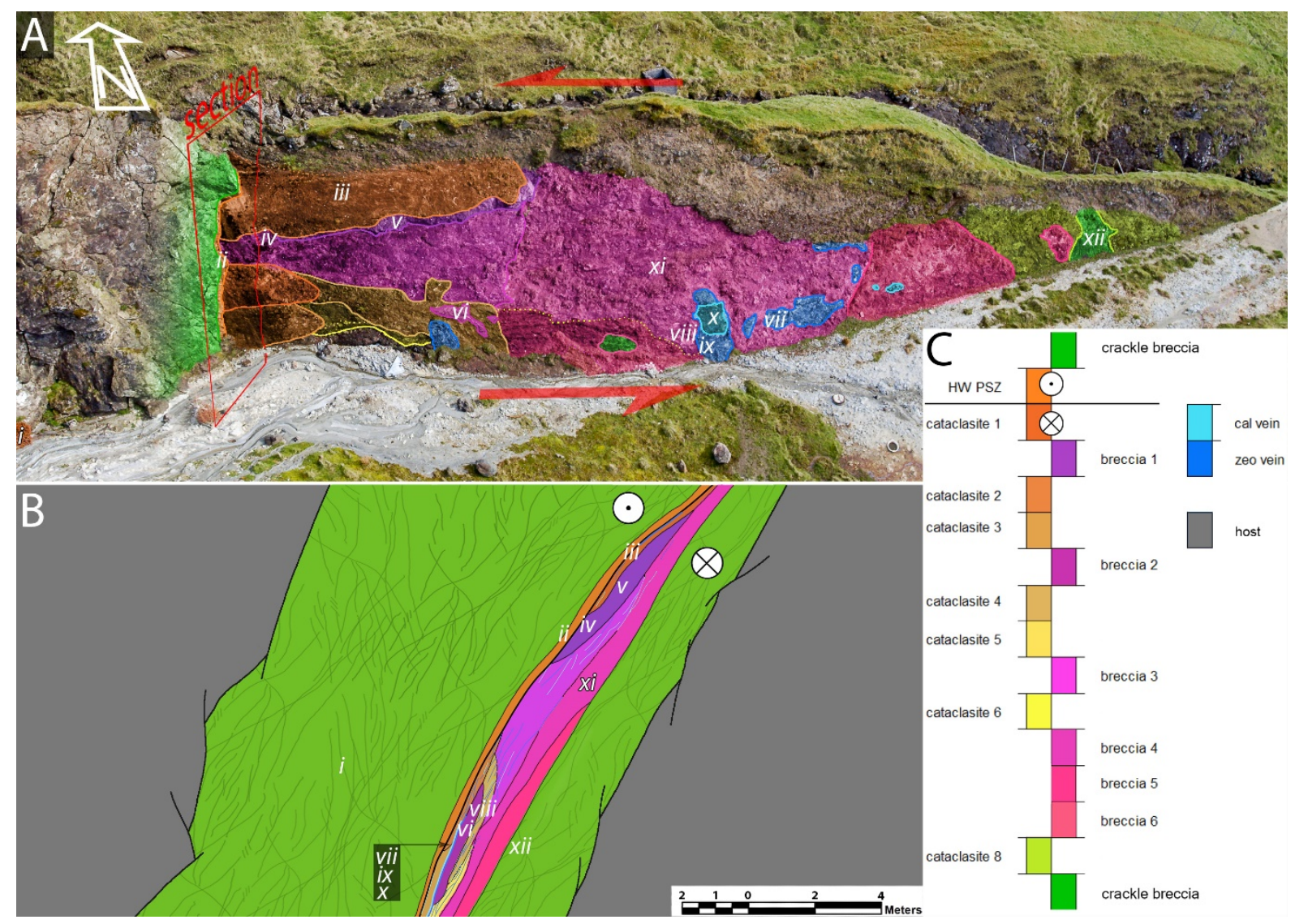

Figure 4: Fault rock distribution in the Gøtugjógv fault zone in the field (A) and in a stylised section (B). The damage zone is mainly composed of a coarse crackle breccia with unaltered host rock clasts. This is contrasted by the highly altered and reworked fault core material which is composed of lenticular fault rock bodies separated by cataclastic shear bands and/or veins. In the PSZ these fault rock lenses mostly contain cataclasite. Closer to the damage zone breccias become more prevalent. They are almost exclusively the result of hydrofracture and are cemented by zeolite or calcite with a texture similar to vein cements. Indices $i-x i i$ refer to samples and micrographs in Figure 8 and Figure 10. 


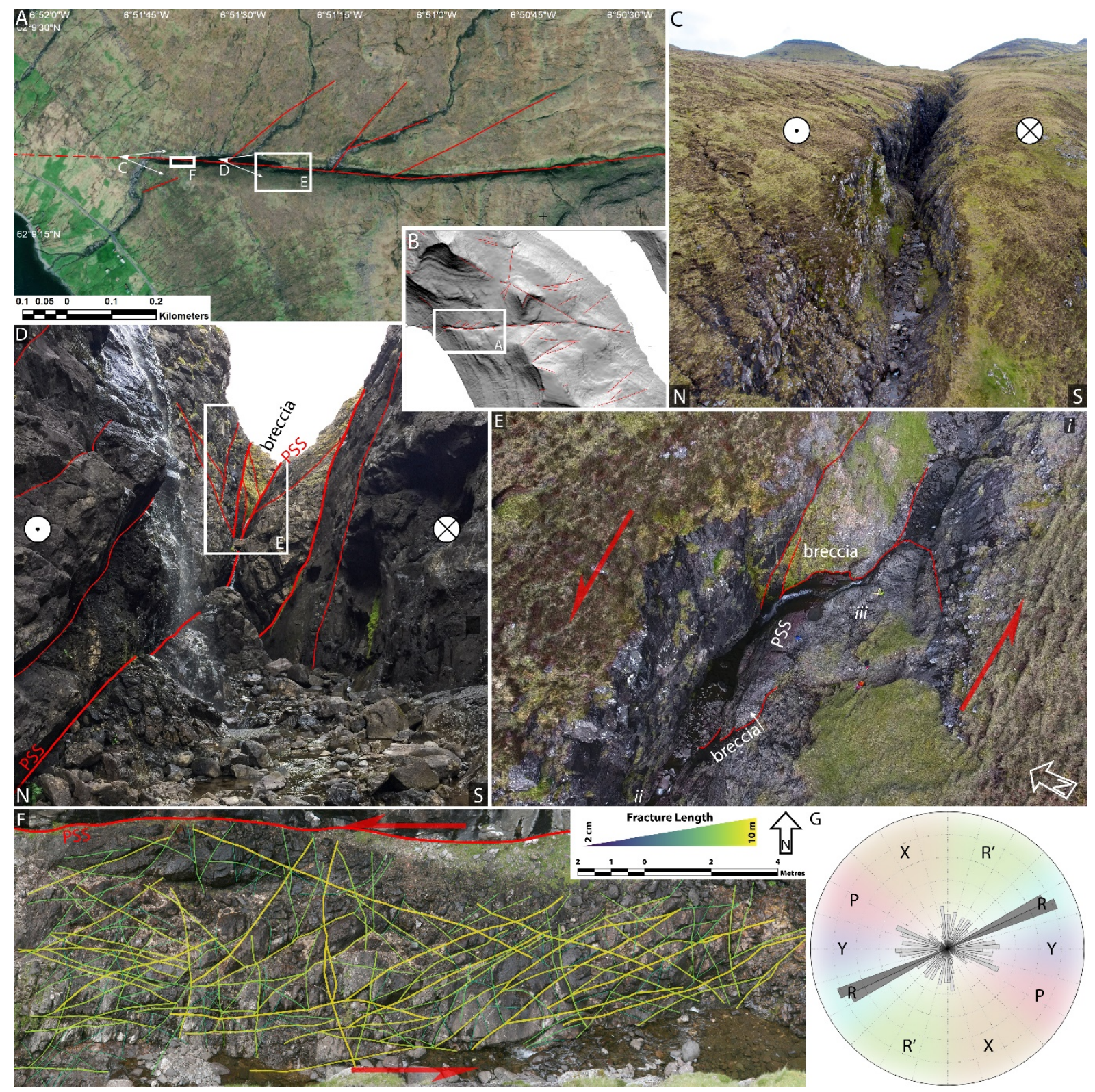

Figure 5: The sinistral Selatrað fault zone can be traced across the entire southwestern peninsula of Eysturoy (B), but is only exposed in two deep gorges on either coast. We focus on the western gorge ( $\&$ \& $C, 62^{\circ} 9^{\prime} 19 . " N 6^{\circ}{ }^{\circ} 1^{\prime} 25^{\prime \prime} W$ ). Smaller faults (in red) in the wider area follow Riedel orientation in the direct vicinity (A) but are less organised further away (B). (D) The overall topographic orientation of the gorge is $000 / 60^{\circ}$ and is presumed indicative for fault zone orientation. PSS and secondary fault mostly run parallel to this trend with a mean orientation of $000 / 71^{\circ}$. (D\&E) The PSS meanders through the fault zone, switching from its southern edge on the upper tier exposed in the $W(E)$ to the northern edge further down (D). The PSS and secondary faults bound lenses of fragmented older fault rock. ( $F \& G)$ Internal fracturing in these lenses is highly systematic and follows the typical Riedel orientation with a very strong dominance of $R$ shears. Indices $i$ - iii in panel $E$ are locations of samples shown in Figure 9. 

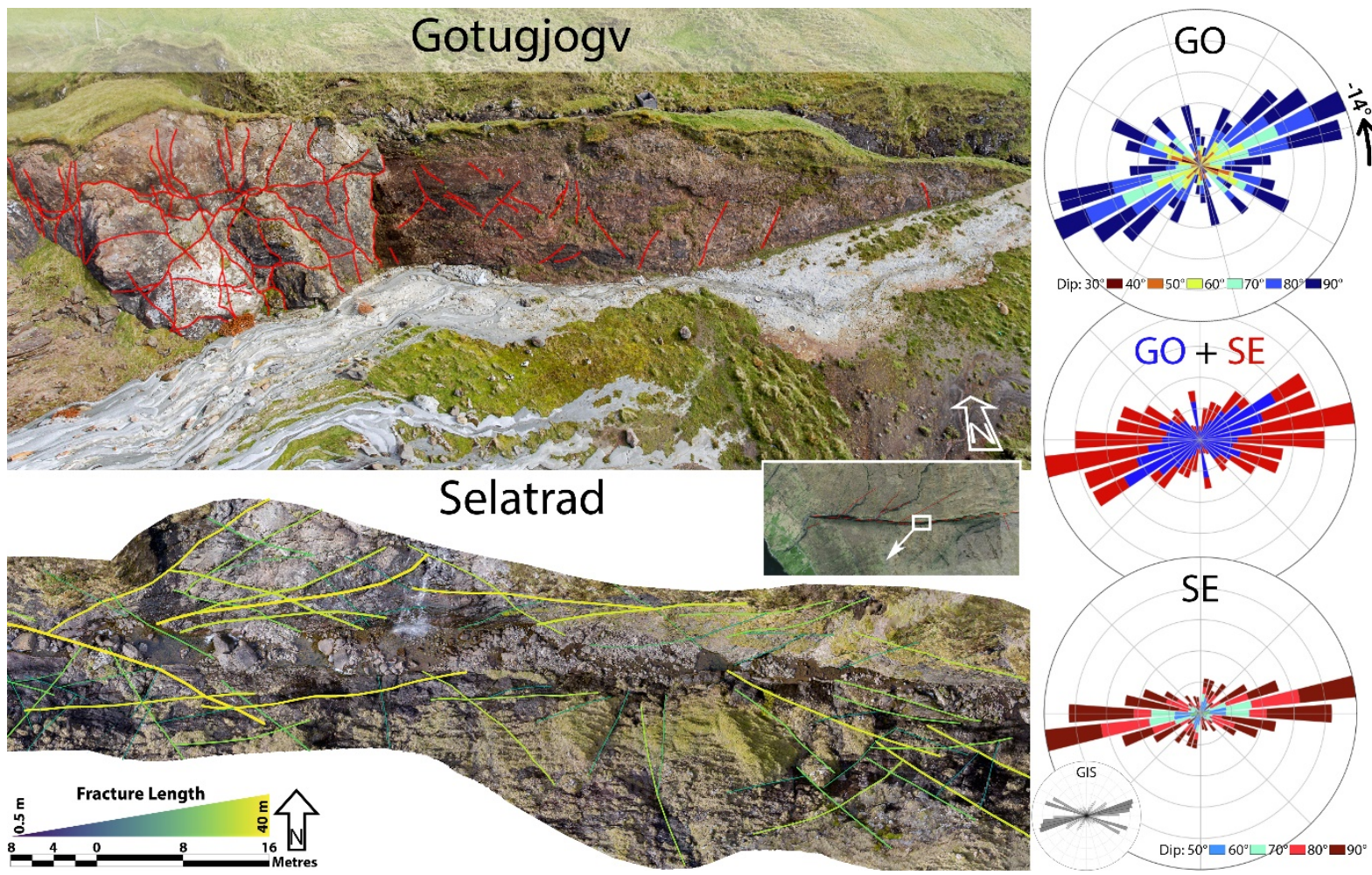

\section{Selatrad}

Figure 6: Comparison between secondary fault orientation in Gøtugjógv and Selatrað. The Gøtugjógv rose plot has been rotated $14^{\circ}$ anticlockwise to match the $E-W$ trend of Selatrad. The data plotted was measured in the field and on fault planes interpreted in the virtual outcrop models. They have been given equal weighing, i.e. half of the data are the field measurements, and the other half are virtual outcrop measurements. The pictures do not represent the plotted data but are rather examples of the general look of the fault zones. The Gøtugjógv data has a more balanced distribution between $R, P, R$ ' and $X$ shears. $Y$ shears are essentially absent because measurements from the PSZ were excluded. The Selatra data is strongly dominated by $Y$ and $R$ shears, most likely because these are very prominent in the gorge, introducing a bias in the field measurements. This becomes clear when comparing to the lineament analysis performed in GIS (inset rose plot), which confirms $R$ frequency recorded in the field and virtual outcrop, but also has a similarly strong peak around the P orientation. In any case, we can see similar trends in both fault zones. $R$ (and $Y$ ) shears are the dominant orientation with subordinate $P$ shears and much less common high angle $R$ ' and $X$ shears. See also Figure ${ }_{5} F$ \& $G$ for smaller scale structures.

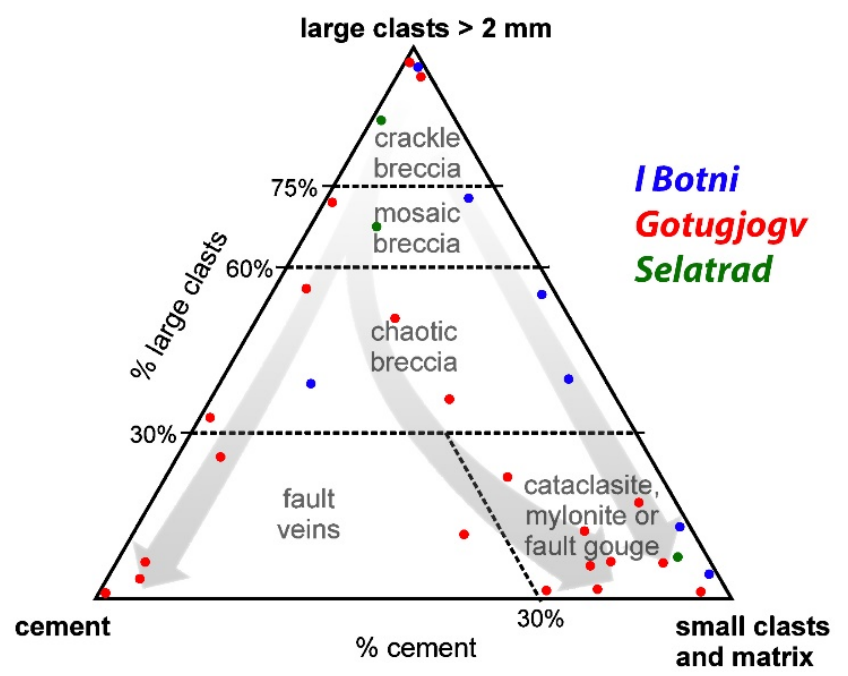

Figure 7: Plotting samples from all 3 fault zones in the fault rock classification diagrams by Woodcock \& Mort (2008) shows that fault rock evolution roughly follows three trends: In the first phase of fault growth (Í Botni, blue), fault rocks are composed almost exclusively of host rock clasts and comminuted matrix. In more mature faults (Gøtugjógv, red \& Selatrað, green), the fault rocks range either on a spectrum of cemented breccias spanning from crackle breccia to veins, or diverge from this trend by accumulating fine grained matrix through cataclasis of clasts and cement from initial brecciation. 

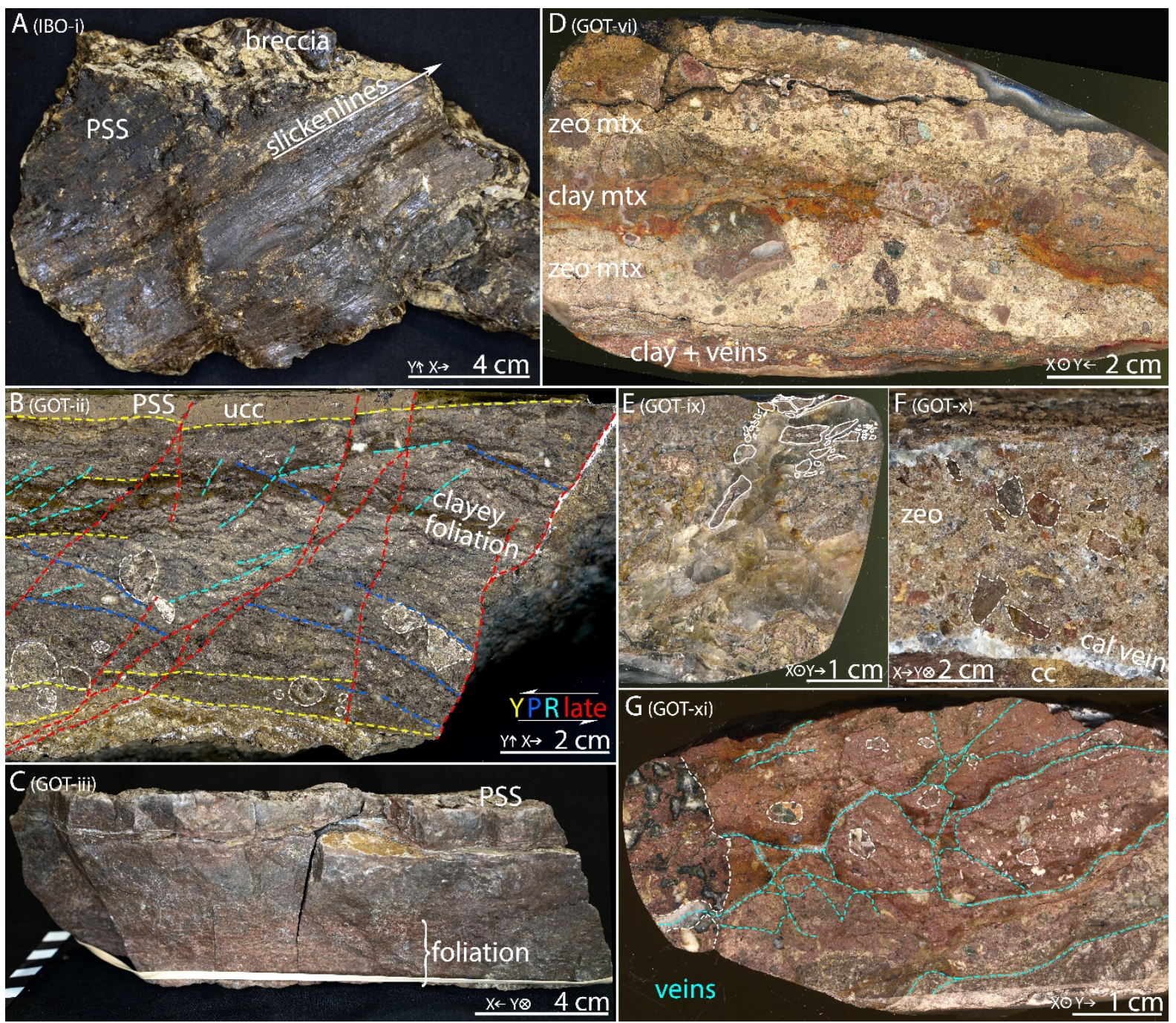

Figure 8: Specimen scale structure of fault rocks: (A) Highly polished and started principal slip surface (PSS) on cataclastic breccias in Í Botni. (B) The hanging wall PSS (sinistral in picture) in Gøtugjógv is defined by a thin layer of ultracataclasite (ucc) separated by $Y$ shears (yellow) from a $5 \mathrm{~cm}$ thick cataclasite with a clayey foliation along $P$ (blue) and $R$ (teal) shears. Both the foliation and the contact are transected by late-stage high angle shears (red). (C) The footwall PSS, on the other hand, is a $>5 \mathrm{~cm}$ thick layer of homogeneous ultracataclasite with a very weak foliation on the far side, which is not distinguishable in thin sections. The boundary cutting across the sample parallel to the PSS is a tabular zeolite-calcite vein. (D) Chaotic breccia of generally fine grained $(<5 \mathrm{~mm})$ clayey fault rock clasts in a zeolite or zeolite + clay matrix (zeo/clay $m t x)$. ( $E \& F)$ Hydrofractured chaotic breccia with fault rock clasts (outlined in white) in coarse equant calcite (E) or fine acicular-bladed zeolite cement (F). (G) Red (ultra-) cataclasite hydrofractured into a crackle breccia with thin zeolite veins. Exemplary clasts are outlined in white. 
1. IBotni

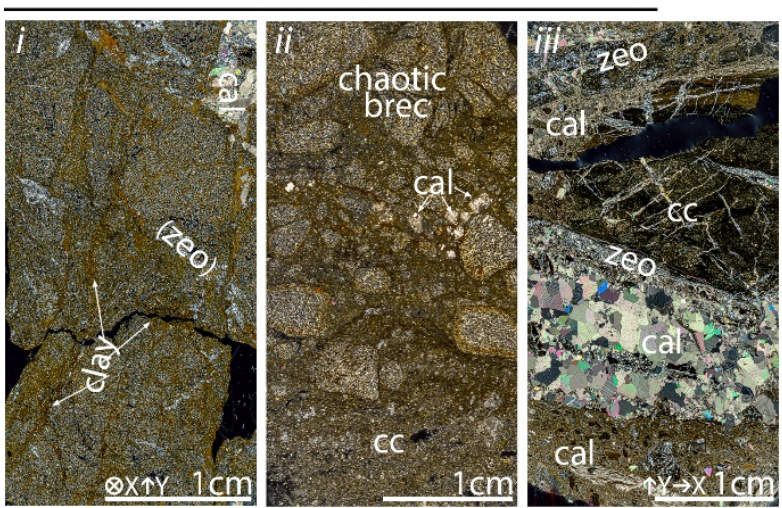

3. Selatrad

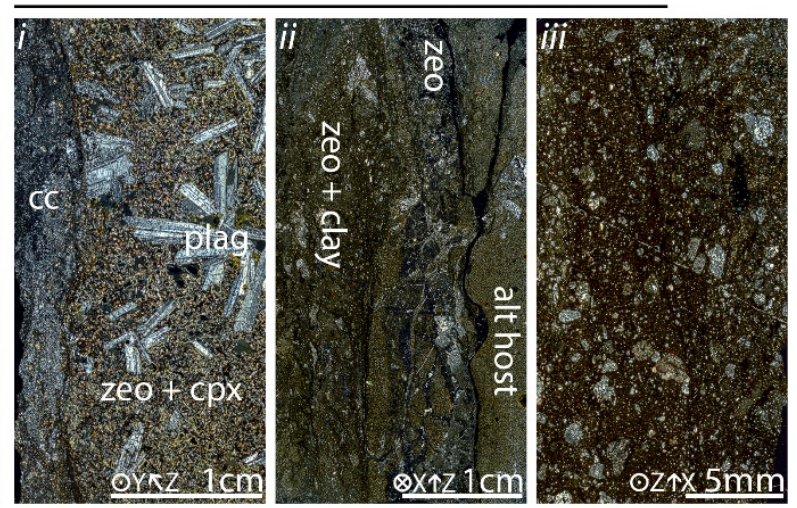

\section{Gotugjogv}
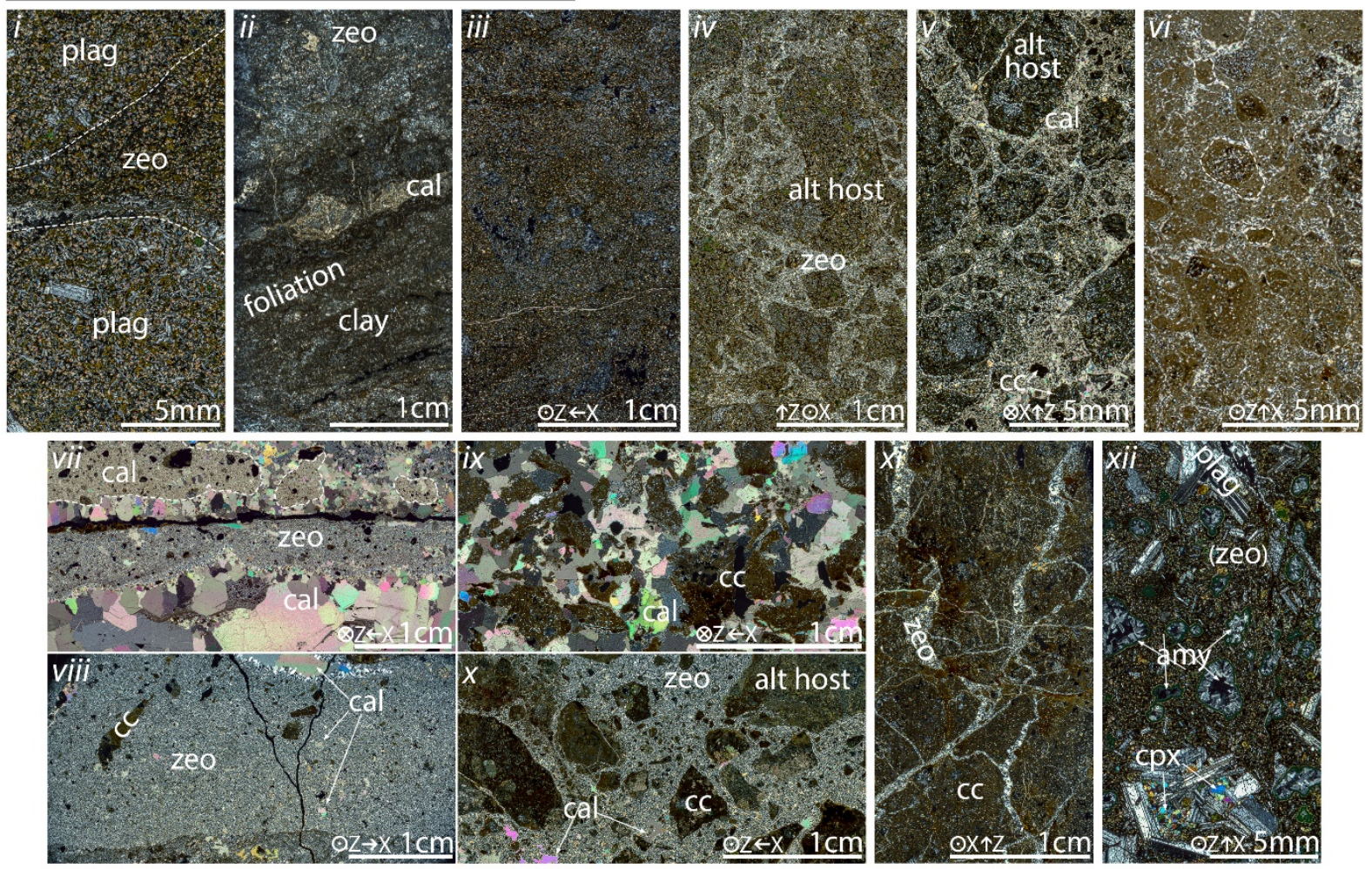

1. IBotni

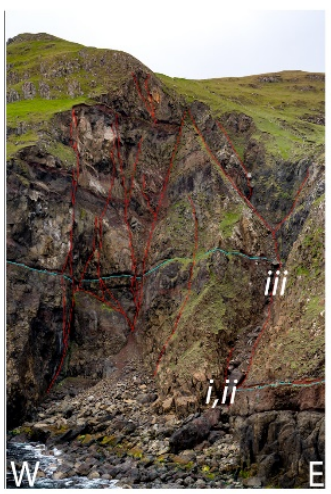

\section{Gotugjogv}

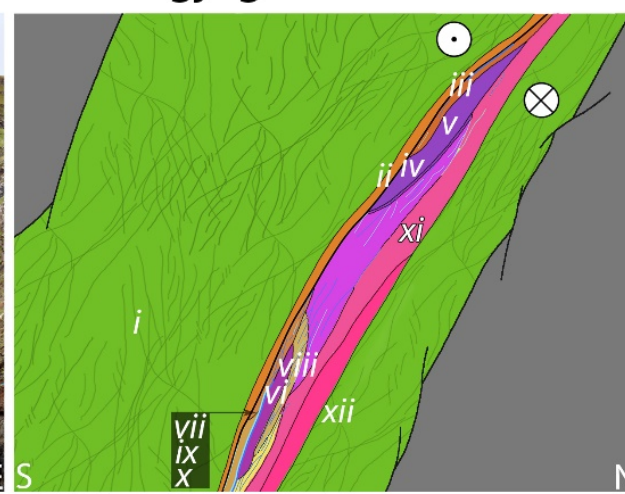

3. Selatrad

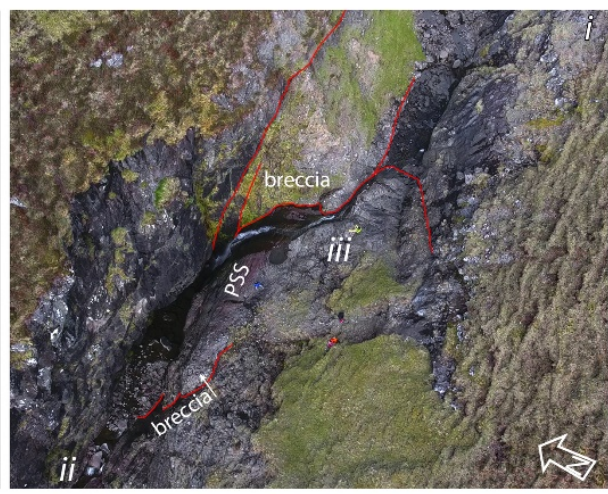

Figure 9: Microstructures as found along fault transects. 1. In the low displacement Í Botni (IBO) fault zone, a PSZ of unconsolidated fault rock is bound by slip surfaces and adjacent mosaic (i) and chaotic (ii) breccias with partially altered matrix in the hanging wall, but also strongly altered breccia-cataclasite in the footwall. 2. Gøtugjógv (i) hanging wall damage zone with fractures delimiting an area of zeolitised host in otherwise unaltered host. (ii) Foliated hanging wall PSS with both clay and zeolite dominated matrix as opposed to (iii) 
thick homogeneous ultracataclasite in the foot wall. The footwall PSZ contains lenses of chaotic breccia with altered host clasts in deformed zeolite (iv) or calcite (v) cement, as well as (vi) reworked fault rock clasts and substantially more clay in the zeolitic cement. The PSZ is also the site of significant veining (vii $-x$ ). Especially thick veins commonly host variable concentrations of wall rock fragments (ix \& $x$ ) but can also reactivate and rework older veins (vii). Their contacts are striated, and deformation is accommodated in a thin shear layer along the boundary (bottom of viii). (xi) Older cataclasite is reworked into a crackle breccia by irregular hydrofracture veins close to (xii) the essentially unaltered (minor matrix zeolitisation) porphyritic damage zone basalt in the footwall. 3. Selatrad features highly altered and localised secondary faults in an otherwise weakly altered damage zone ( $i+i i)$, similar to GOT-xii. The PSS is a homogeneous (ultra-) cataclasite with a clay dominated matrix. Abbreviations: zeo - zeolite, cal - calcite, plag - plagioclase, cc - cataclasite, ucc - ultracataclasite, brec - breccia, amy - amygdale, alt - altered. See Figure 10 for textural details. All micrographs in crossed polarised light.
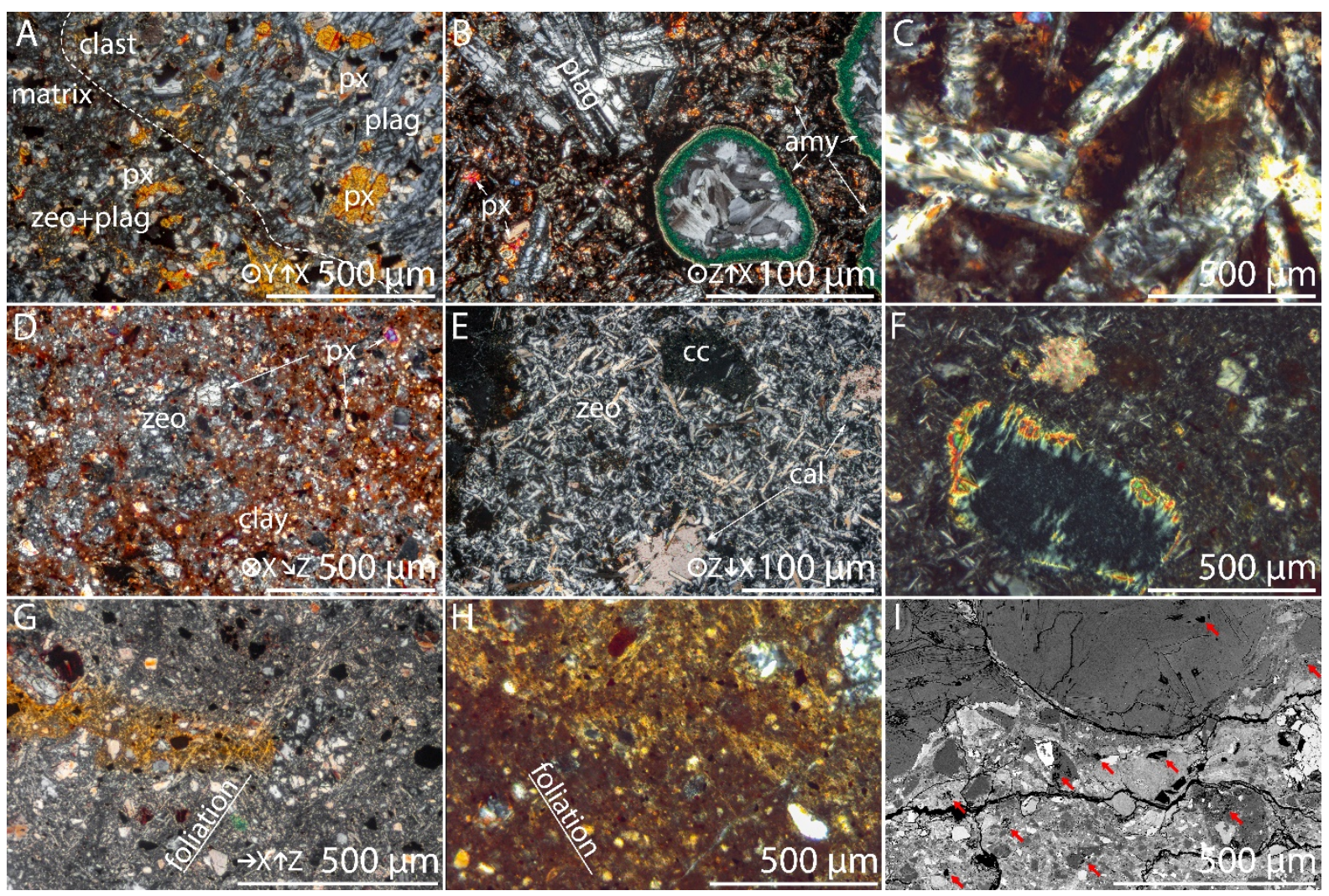

Figure 10: Photomicrographs of textural details: (A - IBO-ii) Í Botni PSZ chaotic breccia with yet unaltered plagioclase in the clasts and partially zeolitised cataclastic matrix. (B - GTO-xii) Gøtugjógv footwall damage zone of relatively unaltered porphyritic basalt clast with zeolite filled amygdales and plagioclase phenocrysts in partially altered groundmass. (C - GOT-iv) Botryoidal zeolite replacing plagioclase in a Gøtugjógv breccia clast. (D - GOT-iii) Homogeneous footwall ultracataclasite from the Gøtugjógv PSS. Shape preferred orientation of zeolite crystals in veins ( $E$ - GOT-viii) and cataclasite matrix ( $F-G O T$-ii) from Gøtugjógv. Also note the euhedral zeolite crystals growing into the calcite pocket in E. Foliation in zeolite (G - GOT-iii) and clay dominated (H - GOT-ii) PSS ultracataclasite, Gøtugjógv. (I - GOTii) Porosity in PSZ cataclasite from Gøtugjógv in SEM-BSE. Abbreviations: Zeo - zeolite, cal - calcite, plag - plagioclase, px - pyroxene, cc - cataclasite. All micrographs except (I) in crossed polarised light. 
Stage 1 - Initial Damage

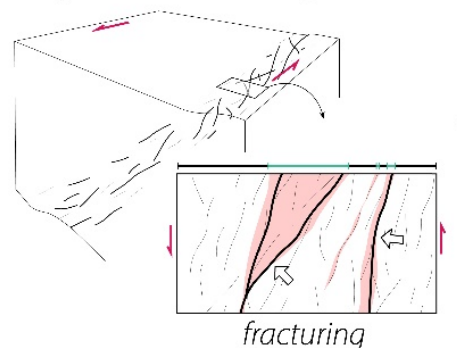

fracturing
Stage 2 - Fault Propagation \& Linkage
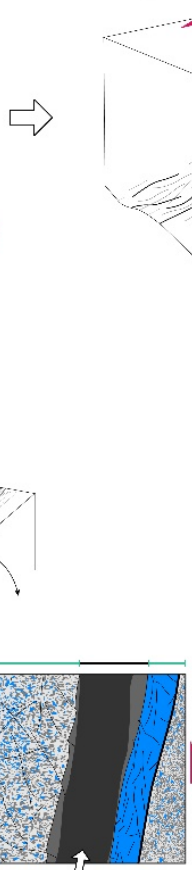

localisation

Stage 7 - PSZ Locking

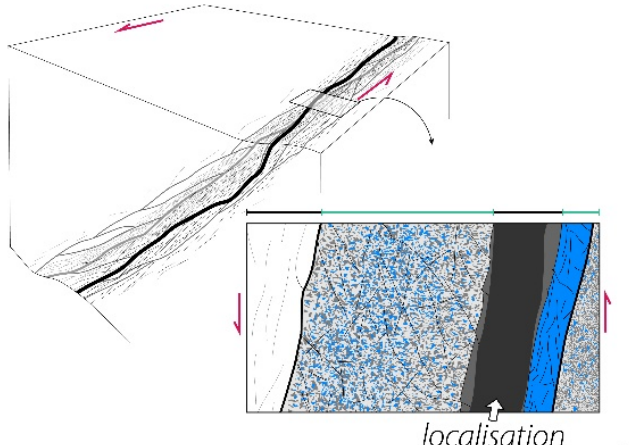

Stage 6 - Cataclasis
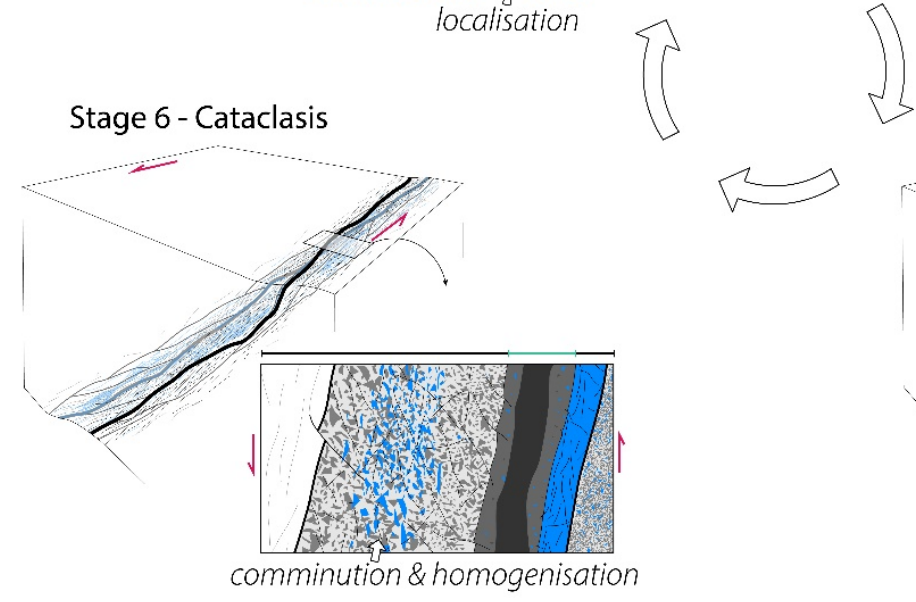

Stage 3 - PSZ Development

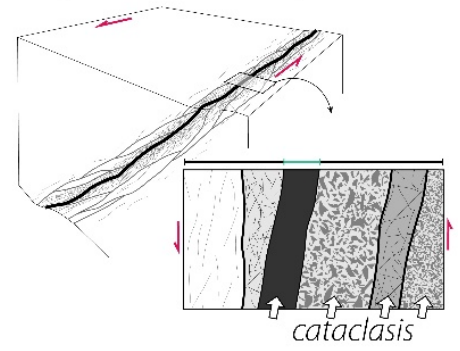

Stage 4 - Hydrofracture

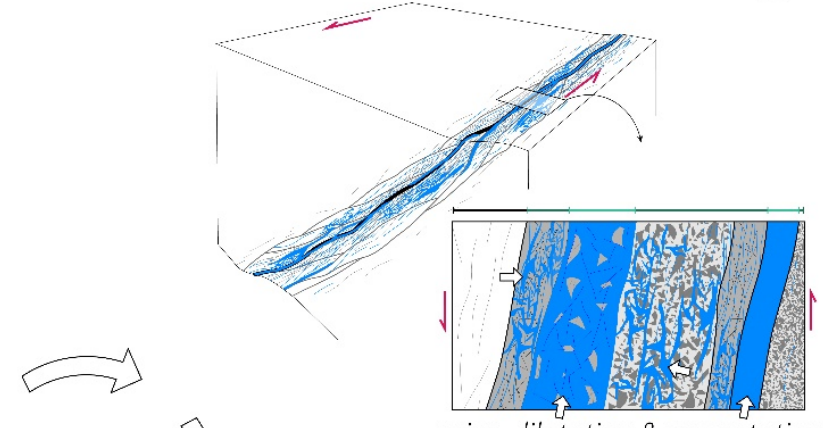

veins: dilatation \& cementation

Principle Slip Surface $\square$ Cataclasite $\square$ Locked Cataclasite $\square$ Vein Breccia LAlteration Fault / Fracture $\rightarrow$ Active vs Passive

Figure 11: Simplified conceptual fault zone evolution in basaltic rock. (Stage 1, GOT-i) Initial distributed damage leads to channelling of fluid flow and associated alteration and weakening of wall rock. (Stage 2, IBO-i - iii) Fault strands linkage followed by slip localisation into cataclastic principal slip zone (PSZ) increases permeability, initiating fluid-mediated alteration of fault rocks. (Stage 3, GOT-iii \& SEL-i) Pervasive fault rock alteration leads to weakening and further slip localisation and cataclasis. (Stage 4, GOT-ix, $x$, xi) Progressive comminution and increasing clay concentration reduce PSZ permeability, culminating in fluid overpressure, hydrofracture, and mineralisation/cementation. (Stage 5, GOT-xi) The now strengthened PSZ is abandoned, and slip migrates to a weaker part of the fault zone. (Stage 6, GOT-v \& vi) The abandoned fault rock is reworked by cataclasis in the vicinity of the newly localised slip zone and integrated into second generation breccia and cataclasite. (Stage 7) Similar to stage 3, cataclasis and alteration in the new PSZ, again, lead to a permeability drop, closing the cycle. (Second entry in parentheses refers to micrographs representing the respective stages in Figure 9.) 


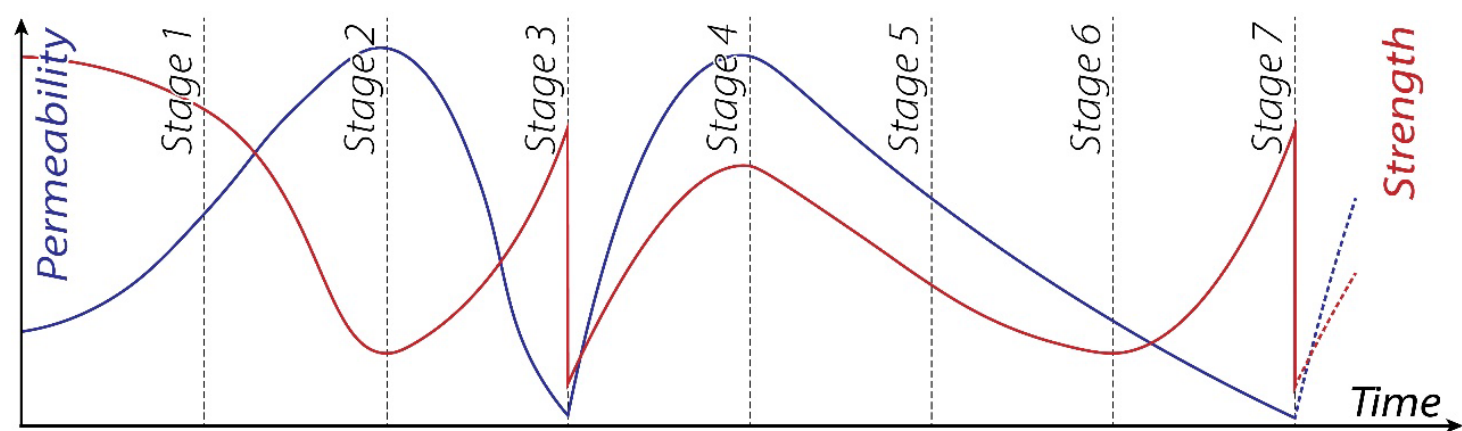

Figure 12: Hypothesised fault-parallel permeability (blue) and strength evolution (red). Stages from Figure 11. 